\title{
Flood inputs in a Mediterranean coastal zone impacted by a large urban area: Dynamic and fate of trace metals
}

\author{
B. Oursel ${ }^{a,{ }^{*},}$, C. Garnier ${ }^{a}$, M. Zebracki ${ }^{b, c}$, G. Durrieu ${ }^{a}$, I. Pairaud $^{b}$, D. Omanović ${ }^{d}$, D. Cossa ${ }^{b, e}$, \\ Y. Lucas ${ }^{a}$
}

\begin{abstract}
a Université de Toulon, PROTEE, EA 3819, 83957 La Garde, France
b IFREMER, Centre de Méditerranée, Laboratoire Environnement Ressources Provence-Azur-Corse, BP 330, Zone Portuaire de Brégaillon, 83507 La Seyne-sur-Mer, France

c IRSN, Laboratoire d'études radioécologiques en milieu continental et marin, CEN Cadarache, 13115 Saint Paul lez Durance, France

${ }^{d}$ Ruđer Bošković Institute, Center for Marine and Environmental Research, PO Box 180, 10002 Zagreb, Croatia

e ISTerre, Université J. Fourier, BP 53, 38041 Grenoble, France
\end{abstract}

\author{
*: Corresponding author : B. Oursel, tel.: + 33494142344 ; fax: + 33494142168 ; \\ email address : oursel@univ-tln.fr
}

\begin{abstract}
:
Trace elements and organic carbon inputs to the Mediterranean sea from an urbanized area (Marseille city) were studied and characterized during flood events. Inputs were brought to the sea by two small coastal rivers whose waters were mixed together and also with treated wastewaters (TWW) just before discharge. The monitoring of the rivers during flood events showed the high temporal dynamics of water flow, suspended particulate matter (SPM), organic carbon and trace metals concentrations, typical of small coastal Mediterranean rivers and requiring an appropriate sampling strategy. Dissolved/particulate partition coefficient (log $K d$ ) in rivers during floods remained quasi-constant for a given trace element, but differed from one element to another according to their affinity toward particles. Because of high SPM concentrations, trace elements were mainly brought to the sea during floods as particles, despite a weaker affinity for particles when compared to baseflow conditions for all studied elements but $\mathrm{Pb}$. If the contribution of TWW dominated the elements baseflow discharge to the coastal zone, rivers outweighed during floods. When discharged to the sea, most trace elements underwent partial desorption in the salinity gradient, especially at highest salinity. Laboratory desorption experiments results were consistent with field data and showed slower desorption kinetics than in baseflow conditions, suggesting that trace elements desorption rates from particles are slower than sedimentation rates. With regard to heavy particles, it results in a potential impact of the sediment on benthic organisms and a possible further desorption after sediment resuspension events. With regard to light particles, it results possible additional desorption during offshore transport.
\end{abstract}




\section{Highlights}

Fast concentration changes during flood events require appropriate monitoring Desorption kinetics from particles in plume slower during floods than baseflow - Untreated wastewaters input resulted in higher contamination by dissolved species D Differences between flood and baseflow particles strongly control metals fate

Keywords : WWTP ; metals contamination ; coastal zone ; flood events ; Mediterranean Sea ; small rivers

\section{Introduction}

Estuaries constitute a transition zone between continent and ocean, and represent a major source of material to the coastal zone. The presence of trace elements in rivers relates to the regional geochemistry and inputs from various anthropogenic sources, especially where population density is high. These anthropogenic inputs are mainly due to leaching of impervious urban surfaces (roads, carparks, roofs) and soil surfaces by runoff, and to sewage overflow from sanitary sewer system during high rainfall events; locally treated wastewaters (TWW) discharge and industrial effluents can also be of importance (Bay et al., 2003, Bothner et al., 2002, Gonzalez et al., 1999, Matthai et al., 2002, Nicolau et al., 2012, Oursel et al., 2013 and Wei et al., 2010). When discharged to the aquatic environment, trace elements can raise toxic levels and cause adverse effects to organisms or even human health (Gupta et al., 2009).

In freshwater/seawater mixing zones such as estuarine systems, the biogeochemistry of trace metals is controlled by a complex interplay of hydrodynamic factors, industrial and 
municipal wastewater discharges and biogeochemical processes. Differences of physicochemical conditions between river and seawater can cause a redistribution of metals between solution and suspended particulate matter (SPM). The geochemical reactivity of trace metals in estuaries is commonly ascribed to changes in metal adsorption-desorption equilibrium and flocculation processes along the salinity gradient (e.g. Boyle et al., 1977; Zwolsman et al., 1997; Thill et al., 2001). Mobilization of dissolved metals from solid phase is indeed the subject of considerable interest and numerous field data confirm the significance of metal release from river SPM along the salinity gradient (Elbaz-Poulichet et al., 1996; Kraepiel et al., 1997; Waeles et al., 2005; Audry et al., 2007). The morphological characteristics of the river watershed as climate, catchment area hydrology, geology and land use, and the physicochemical characteristics of the water column as mixing time of waters or metal speciation can be decisive (Nicolau et al., 2012).

The Mediterranean environment is known for its high-intensity rains, promoting high rates of terrestrial runoff that can occur after long dry periods which allow contaminants accumulation in the watershed surfaces. The spatial and seasonal variability of rainfall follows a complex pattern, with wide and unpredictable rainfall fluctuations from one year to another (Martínez-Casasnovas et al., 2002; Nicolau et al., 2012). Numerous studies focused on Rhône River, the main river of the western Mediterranean basin and the largest contributor with regard to water and SPM discharge to the Mediterranean Sea (Ollivier et al., 2011; Radakovitch et al., 2008; Raimbault and Durrieu de Madron, 2003). Small coastal rivers, despite their low flows, can also have a high ecological impact because they rapidly bring to the sea the contamination occurring in the coastal area, especially where population density is high, however only few studies dealt with small Mediterranean rivers impacted by urbanization (Dassenakis et al., 1997; Elbaz-Poulichet, 2005; López-Flores et al., 2003; Nicolau et al., 2012; Oursel et al., 2013). In Marseille agglomeration (1.7 million inhabitants), Huveaune and Jarret rivers constitute a typical example of such rivers. Their watersheds are representative of modern anthropization in most of the Mediterranean coastal strip, mixing urban, semi-urban, small industrial and some preserved natural areas. Their waters are mixed together and with city wastewater treatment plant (WWTP) effluents before their outlet to the sea (Fig.1) at the Calanque of Cortiou, situated in the French National Park of "Calanques". Studies on the dynamics of elements in transitional coastal zone (e.g. estuaries) are well documented (Elbaz-Poulichet et al., 1996; Ollivier et al., 2011; Shiller, 1997; Waeles et al., 2008), but a system such as Marseille is quite specific. Oursel et al. (2013) have demonstrated that the WWTP effluents represent the main source of inorganic contaminants brought to the 
coastal zone during baseflow periods. During flood events, the relative contributions of rivers $v s$. WWTP effluents are likely different. Indeed, studying experimentally the fate of Marseille watershed particles and associated pollutants when discharged to the coastal zone, Oursel et al. (2014) have observed that characteristics of particles from flood events were dominated by that of rivers waters, except during WWTP by-pass.

In this context, the aims of the present study were (1) to quantify and characterize carbon and trace metals dynamics and inputs to the sea during flood events in comparison to baseflow periods and (2) to understand the mechanisms governing elements behaviour and fate in the mixing zone during these contrasted conditions.

\section{Material and methods}

\subsection{Study site}

Huveaune River extends over $48.4 \mathrm{~km}$ long and runs through a watershed with an area of $523 \mathrm{~km}^{2}$ which consists in karstic formation (60\%) and detrital sediments. Land-use in the downstream part of the watershed is urban and industrial. Jarret River extends over $21 \mathrm{~km}$ with a $102 \mathrm{~km}^{2}$ watershed mainly urban and industrial. For the period 1961-2009, the mean annual precipitation in Marseille was $544 \mathrm{~mm}$ and the mean number of days with total rainfall of $1 \mathrm{~mm}$ or more was 59 (Infoclimat, 2014).

In baseflow period, these two rivers merge in Marseille; the resulting water is mixed with the Marseille City WWTP effluents, and then channelled and discharged at sea at the Calanque of Cortiou (Fig. 1). This treatment plant, one of the largest in Europe (1.7 million inhabitant eq.), uses both physical and biological treatment processes. During baseflow periods ( 300 days), around 100 and $80 \mathrm{Mm}^{3} \mathrm{y}^{-1}$ of TWW and river water, respectively (average flows of 1.9 and $0.9 \mathrm{~m}^{3} \mathrm{~s}^{-1}$ for Huveaune and Jarret, respectively), are discharged to the sea (Le Masson, 1997). The corresponding annual SPM discharge is around $3950 \mathrm{t}$, of which $850 \mathrm{t}$ are coming from rivers, highlighting the main contribution of TWW in such conditions (Jany et al., 2012; Oursel et al., 2014). During flood events, Huveaune and Jarret Rivers flows can overpass 60 and $16 \mathrm{~m}^{3} \mathrm{~s}^{-1}$, respectively. During such extreme events, as the maximal outlet discharge capacity cannot exceed $30 \mathrm{~m}^{3} \mathrm{~s}^{-1}$, the exceeding part of rivers waters is channelled through the Huveaune former bed to the Prado's beach (Fig. 1). During rainy periods, around 4.1 and $11 \mathrm{Mm}^{3} \mathrm{y}^{-1}$ of TWW and rivers waters, respectively, are discharged to the sea. Le Masson (1997) has evaluated the corresponding SPM discharge to be 6500 t, $94 \%$ 
coming from rivers. On average, during flood events, 90\% of Huveaune and Jarret waters (and SPM) are channelled through the outlet and only $10 \%$ are deviated through the Huveaune former bed. Additionally, discharge of untreated wastewater (due to WWTP bypass) brought to the coastal zone ranged between 456 and $1450 \mathrm{t} \mathrm{y}^{-1}$ of SPM during the period 2001-2007 (Jany et al., 2012).

\subsection{Sampling}

All bottles (FEP and HDPE, from Nalgene) used throughout the whole sampling and conditioning were previously cleaned with $10 \% \mathrm{HNO}_{3}\left(\mathrm{HNO}_{3} 70 \%\right.$ Analytical reagent grade, Fisher Scientific), rinsed with milliQ water (Millipore 18.2 M 2 ), filled with milliQ water and acidified at $0.1 \%$ with suprapur (s.p.) $\mathrm{HNO}_{3}$ (Merck) until use. Main physico-chemical parameters (T, $\mathrm{S}, \mathrm{pH}, \mathrm{O}_{2}$, conductivity) were measured on-field using a HACH LANGE multi-probe, calibrated before each campaign.

\subsubsection{Freshwater sampling}

In order to characterize rivers inputs during a flood event, a monitoring of Huveaune and Jarret Rivers in rainy conditions was performed on 18/09/2009. The sampling stations were immediately located upstream the river confluence. In order to have representative samples, nine composite samples were collected from 8:00 am to 8:20 pm by sampling $100 \mathrm{~mL}$ of the river water using an HDPE bucket each 10 min during $1 \mathrm{~h}$ or each 20 min during $2 \mathrm{~h}$, depending on the intensity of the rain and the rivers flow. Rivers were also sampled one day before and one day after the flood to characterize river baseflow. Then, 6 additional rain samples were collected at various dates after this monitoring to better take into account the inputs variability and to more accurately evaluate their contribution to the average flux of elements to the coastal zone.

A monitoring of WWTP effluent and rivers waters mixing at the outlet was also performed from 18/09/2009 7:00 am to 20/09/2009 7:00 am, using an automatic sampler (mobile refrigerated automatic sampler, Hydreka) installed in the outlet, thanks to the logistic of the SERAM company and IFREMER. During these 48 hours, 24 composite samples of 900 $\mathrm{mL}$ were collected by sampling $150 \mathrm{~mL}$ of water every $20 \mathrm{~min}$ during $2 \mathrm{~h}$. Rainfall data were provided by Meteo-France, river flows by SERAM and DEA. 


\subsubsection{Seawater sampling}

In rainy conditions, the accessibility to the study site was difficult as rain was often accompanied with strong wind and big waves, so only 3 sampling campaigns (25/10/2011, 21/05/2012 and 28/11/2012) were conducted. Two of them were performed at the Calanque of Cortiou and the 25/10/2011 campaign was performed at the Prado beach.

During each campaign, sampling was performed along a transect (Fig. 1, inset) situated in the plume. Depending on weather conditions and plume length, 5 to 11 surface samples were taken from the outlet to the defined marine end-member ( $2 \mathrm{~km}$ offshore and $4 \mathrm{~m} \mathrm{depth})$. Considering the high stratification of the plume, sampling was performed using a 2.2 horizontal sampler (Wildco) which allows sampling within a ten-centimeter thick layer. Samples were partitioned in $1 \mathrm{~L}$ FEP bottles for metal analysis and $1 \mathrm{~L}$ HDPE bottles for organic matter $(\mathrm{OM})$ analysis. After sampling, bottles were stored in cooler, brought back to the laboratory and immediately filtered (in-lab filtration). Additionally, for these 3 campaigns, at each sampling site an aliquot was also immediately filtered on board (on-field filtration) to avoid trace elements dissolved/particulate repartitioning which can alter the assessment of their behaviour along the salinity gradient (Oursel et al., 2013).

The 3 flood campaigns will hereafter be compared to 2 contrasted baseflow conditions campaigns already described in Oursel et al. (2013): a 22/03/2011 campaign with typical baseflow conditions, and a 18/04/2012 campaign characterized by a planned by-pass of the WWTP (due to servicing).

\subsection{Sample filtration, conditioning and treatment}

Samples for organic carbon analyses were filtered through $25 \mathrm{~mm}$ glass fiber filters (Whatman GFF, $0.7 \mu \mathrm{m})$. Filters were dried $\left(40^{\circ} \mathrm{C}\right)$ until constant mass and stored in aluminium paper until particulate organic carbon (POC) quantification. The dissolved fraction was preserved with $25 \mu \mathrm{L} 1 \mathrm{M} \mathrm{NaN}_{3}\left(\mathrm{NaN}_{3}>99 \%\right.$, Aldrich) and stored at $4^{\circ} \mathrm{C}$ in $24 \mathrm{~mL}$ glass tubes (Wheaton, equipped with Teflon/silicone septum) prior to analysis of dissolved organic carbon (DOC). All tubes, filters and glass filtering systems (Wheaton) were previously cleaned with $10 \% \mathrm{HNO}_{3}$, rinsed with MilliQ water and calcinated during $4 \mathrm{~h}$ at $450{ }^{\circ} \mathrm{C}$.

Samples for dissolved/particulate metal analyses were filtered through $47 \mathrm{~mm}$ precleaned (rinsed with $100 \mathrm{~mL}$ of MilliQ water) cellulose nitrate filters (Sartorius, $0.45 \mu \mathrm{m}$ ). Filters were then dissolved by microwave digestion (AntonPaar Multiwave 3000) in aqua 
regia (trace metal grade acids, Fisher Scientific) for further analysis of metals in the particulate fraction, following the procedure previously validated (Tessier et al., 2011). The dissolved fraction was stored in $60 \mathrm{~mL}$ FEP bottles, acidified with $60 \mu \mathrm{L} \mathrm{HNO}_{3}($ Merck Suprapur) and digested $2 \mathrm{~h}$ under UV-irradiation (Metrohm 705, $500 \mathrm{~W}$ ), a necessary step for stripping voltammetry analysis of total dissolved metal concentrations.

On-field filtration was achieved using $0.2 \mu \mathrm{m}$ in-line syringe cellulose nitrate filters (Sartorius). Filtrates were stored in $60 \mathrm{~mL}$ FEP bottles for dissolved metals analysis and in 24 $\mathrm{mL}$ glass tubes for DOC analysis. The filtrates were then processed as described for in-lab filtrations.

\subsection{Remobilization experiment}

For a better understanding of the mechanisms governing trace metals behaviour in the salinity gradient, a remobilization experiment designed to simulate mixing of outlet effluent with seawater was performed in the laboratory. During baseflow period, a $10 \mathrm{~L}$ composite outlet water (Outlet baseflow) was sampled by collecting ten times $1 \mathrm{~L}$ during $~ 15 \mathrm{~min}$, in order to obtain a more representative outlet sample. Flood deposit collected in the outlet (FDOut2, Oursel et al., 2014) was added in this composite sample in order to obtain an "artificial flood" outlet sample (SPM close to $800 \mathrm{mg} \mathrm{L}^{-1}$ ) and equilibrated during $24 \mathrm{~h}$. Filtered marine "end-member" (Oursel et al., 2013) was mixed in $500 \mathrm{~mL}$ FEP bottles with the artificial flood outlet water to cover the following range of salinity: 1, 2.5, 5, 10, 20 and 30. The $500 \mathrm{~mL}$ FEP bottles were installed on an head-over-head agitation system (Reax 20, Heildolph) and aliquots were sampled at $15 \mathrm{~min}, 1,6$ and $24 \mathrm{~h}$ of mixing time using precleaned syringe, then filtered through pre-cleaned in-line filters (Sartorius, $0.2 \mu \mathrm{m}$ ). Filtrates were stored and analyzed for DOC and dissolved trace metals as explained in section 2.5.

\subsection{Sample chemical analysis}

\subsubsection{Dissolved and particulate carbon analysis}

The organic carbon content was determined using the high-temperature $\left(900^{\circ} \mathrm{C}\right)$ catalytic oxidation method with $\mathrm{CO}_{2}$ IR detection (Ammann et al., 2000; Callahan et al., 2004), calibrated using glucose (Analytical reagent grade, Fisher Scientific) with an accuracy of 8.3 $\mu \mathrm{M}$ C. POC contents were determined on GFF filters using a TOC- $\mathrm{V}_{\mathrm{CSH}}$ analyzer (Shimadzu), 
coupled with a SSM-5000A module. GFF filters were dried to constant weight at $60^{\circ} \mathrm{C}$, and then exposed to $\mathrm{HCl}$ fumes for $4 \mathrm{~h}$ to remove all the inorganic carbon (Lorrain et al., 2003).

DOC and DIC concentrations were determined using the same TOC- $\mathrm{V}_{\mathrm{CSH}}$ analyzer, calibrated using potassium hydrogenophtalate (Shimadzu) and $\mathrm{NaHCO}_{3} / \mathrm{Na}_{2} \mathrm{CO}_{3}$ (Shimadzu) standard solutions, respectively, with an accuracy of 1.7 $\mu \mathrm{M} \mathrm{C}$ (Louis et al., 2009). DOC and DIC analysis were validated using certified reference material (MISSIPPI-03, Canada); the obtained values were within the certified limits.

\subsubsection{Minor and trace elements analysis}

In the following, concentration and content terms refer to mass/mol per volume unit (e.g. $\mathrm{nM}$ ) and mass/mol per mass unit (e.g. $\mu \mathrm{mol} \mathrm{g}^{-1}$ ), respectively

\subsubsection{Dissolved trace metals in saline samples}

Total dissolved metal concentrations were determined by Differential Pulse Anodic Stripping Voltammetry $(\mathrm{Cd}, \mathrm{Cu}, \mathrm{Pb}$ and $\mathrm{Zn})$ and Differential Pulse Adsorptive Cathodic Stripping Voltammetry (Co and $\mathrm{Ni}$ ) using fully automated analytical procedures previously described (Louis et al., 2009; Omanović et al., 2006; Oursel et al., 2013). Total dissolved As was determined using a hydride generation atomic fluorescence spectrometry (HG-AFS) technique (ThermoScientific - PS Analytical) (Dang et al., 2014).

Analysis were validated using certified "Nearshore Seawater Reference Material for Trace Metals" - CASS5 (NRC CNRC). All metals determinations were within the certified limits.

\subsubsection{Particulate minor and trace elements and dissolved trace elements in freshwater} samples

Particulate elements (Ag, Al, $\mathrm{As}, \mathrm{Cd}, \mathrm{Co}, \mathrm{Cr}, \mathrm{Cu}, \mathrm{Fe}, \mathrm{Li}, \mathrm{Mn}, \mathrm{Ni}, \mathrm{Pb}, \mathrm{V}$ and $\mathrm{Zn}$ ) were quantified from the acid-digested filters by High Resolution Inductively Coupled Plasma Mass Spectrometry (HR ICP-MS Element 2, Thermo Finnigan). Blanks didn't overpassed $10 \%$ of the elements concentrations measured on samples and consequently were not substracted from these values. The instrument was calibrated using standard solutions and indium was used as an internal standard to correct for changes in peak intensities due to instrumental drift (Lenoble et al., 2013). Quality control of HR ICP-MS measurements was checked by the determination of elements concentration on Certified Reference Material 
(SLRS-4 river water, PACS-2 sediment, National Research Council Canada). All results fell in the range of the certified data.

\section{Results and Discussion}

\subsection{Dynamic of elements in rivers during flood event}

Table 1 gives the average of the measured parameters in Huveaune and Jarret Rivers, at the outlet and in the marine end-member during the flood, compared to those observed during floods in Eygoutier River, a small coastal river of the same geographic area (Nicolau et al., 2012) and to those observed in floods of Rhône River (discharge over $1500 \mathrm{~m}^{3} \mathrm{~s}^{-1}$ ), the main river of the French Mediterranean area (Ollivier et al., 2011).

Figure 2A represents the discharge in rivers and the rainfall at Marseille ("MARSEILLEOBS" Météo-France rain gauge) as a function of time during the 18/09/2009 flood. A first 14 mm-rainfall between 7:00 and 9:00 am resulted in a fast increase of the river discharge with a maximum of $28 \mathrm{~m}^{3} \mathrm{~s}^{-1}$ in Huveaune River and $10 \mathrm{~m}^{3} \mathrm{~s}^{-1}$ in Jarret River. A second $11 \mathrm{~mm}$ rainfall between 3:00 and 6:00 pm resulted in an increase of the river flows with a maximum of $22 \mathrm{~m}^{3} \mathrm{~s}^{-1}$ in Huveaune River and $6.6 \mathrm{~m}^{3} \mathrm{~s}^{-1}$ in Jarret River. Contrarily to Huveaune, the flow of Jarret returned at its baseflow (around $1.6 \mathrm{~m}^{3} \mathrm{~s}^{-1}$ ) less than two hours after the rainfall. These results attested the high reactivity and dynamic of this urbanized system, a specificity common to most of the small Mediterranean rivers submitted to extreme events.

\subsubsection{Suspended particulate matter}

Figure 2B shows the suspended particulate matter (SPM) and the turbidity in the rivers as a function of time during the same day. For both rivers, SPM and turbidity were highly correlated (data not shown, $\mathrm{R}^{2}=0.94$ ), increasing during the rain and decreasing after, with a maximum (1-h composite value) for the first rain at $256 \mathrm{mg} \mathrm{L}^{-1}$ and $248 \mathrm{mg} \mathrm{L}^{-1}$ for Huveaune and Jarret Rivers, respectively. Both rivers presented similar SPM time variations and maximal values despite much lower flow in the Jarret River. However, between the 2 rain events, SPM concentrations in Jarret River return to baseflow values when Huveaune River ones remained 4-fold higher. The flood carried SPM concentrations 20 times higher, on average, than in baseflow conditions (Oursel et al., 2013), but were in the same range of 
concentrations than in Eygoutier River floods and even lower than in Rhône River floods (Table 1).

\subsubsection{DOC, POC, DIC and conductivity}

In both rivers, DOC was on average 3-fold higher during flood than during baseflow periods (Table 1). Figure 2C represents DOC and POC concentrations for both rivers as a function of time during the same flood. DOC and POC concentrations showed similar variations $\left(\mathrm{R}^{2}=0.85\right)$, increasing at the beginning of each rain as already observed in other systems (Nicolau et al., 2012; Shafer et al., 1997; Tao, 1998; Wu et al., 2013), with a maximum for DOC at 480 and $720 \mu \mathrm{M} \mathrm{C}$ and for POC at 1700 and $1250 \mu \mathrm{M} \mathrm{C}$ for Huveaune and Jarret Rivers, respectively. However, Nicolau et al. (2012) have shown that very different patterns between DOC and POC can be observed from one flood event to another. The variations of DOC concentrations as a function of POC concentrations for baseflow and floods in rivers and at the outlet are plotted in Figure 3A. For baseflow conditions, in Huveaune River, DOC fraction is dominant whereas in Jarret River, it is POC (Oursel et al., 2013). At the outlet, DOC and POC are in the same range, both strongly increasing in comparison to river values (Oursel et al., 2013). During floods, DOC and POC increased in both rivers, POC being the major fraction. There is no significant difference between outlet and rivers values, indicating that the WWTP signature was overriden by the rivers water, on contrary to baseflow conditions (Oursel et al., 2013).

POC expressed in content (i.e. $\mu$ molC $\mathrm{g}_{\mathrm{SPM}}{ }^{-1}$ ) didn't shown significant variation during the flood (data not shown) but was significantly lower than in baseflow conditions, likely because the enrichment of SPM by mineral particles due to erosion processes resulted in a dilution of POC.

In both rivers, DIC and conductivity decreased with increasing discharge, reaching minimal values of 1250 and $1060 \mu \mathrm{M} \mathrm{C}$ for DIC and 0.21 and $0.17 \mathrm{mS} \mathrm{cm}^{-1}$ for conductivity for Huveaune and Jarret Rivers, respectively (data not shown), due to the dilution of river water by rain water (baseflow levels: 4080 and $3080 \mu \mathrm{M} \mathrm{C}, 0.71$ and $0.61 \mathrm{mS} \mathrm{cm}^{-1}$ for Huveaune and Jarret Rivers, respectively). The good linear correlation $\left(\mathrm{R}^{2}=0.93\right)$ between conductivity and DIC was expected as conductivity was mostly controlled by DIC (carbonates and $\mathrm{Ca}$ ) and corresponded to the calcareous signature of the rivers watersheds. 


\subsubsection{Minor and trace elements}

\subsubsection{Particulate and dissolved metal concentrations}

Particulate concentrations ( $\mu \mathrm{M}$ ) of $\mathrm{Ag}, \mathrm{Al}, \mathrm{Cd}, \mathrm{Co}, \mathrm{Cr}, \mathrm{Cu}, \mathrm{Fe}, \mathrm{Li}, \mathrm{Mn}, \mathrm{Ni}, \mathrm{Pb}, \mathrm{V}$ and $\mathrm{Zn}$ were well correlated to SPM $\left(0.53 \leq \mathrm{R}^{2} \leq 0.78\right.$ for Huveaune River, $0.68 \leq \mathrm{R}^{2} \leq 0.93$ for Jarret River $(\mathrm{p}<0.05)$ ). Their average concentrations were similar in the two rivers (Table 1). Some differences, however, were observed between metals. In Huveaune River, particulate $\mathrm{Cu}, \mathrm{Pb}$, $\mathrm{Cd}, \mathrm{Zn}$ and $\mathrm{Ni}$ were much more concentrated during the second rain despite a lower SPM concentration (Fig. 2B and 2D). Oppositely, particulate Co was evenly distributed between the 2 rains. In Jarret River, particulate $\mathrm{Cu}, \mathrm{Pb}, \mathrm{Cd}$ and $\mathrm{Zn}$ were more concentrated during the first rain and particulate $\mathrm{Co}$ and $\mathrm{Ni}$ concentrations were evenly distributed between the 2 rains. Between the 2 rain events, particulate organic carbon and metals concentrations rapidly returned to baseflow values in Jarret River, confirming the high reactivity of this river, due to the predominance of impervious surface areas in the watershed.

The behaviour of dissolved metals in rivers during the flood was also different between each rain and rivers. Dissolved $\mathrm{Cu}$ is given as an example in Figure 2D. In Huveaune River, dissolved $\mathrm{Cu}$ increased at the beginning of each increasing flood, decreased during the flow peak and returned close to the baseflow concentration between the 2 rains, whereas in Jarret River, it decreased with increasing flow and increased between the two rains. Dissolved $\mathrm{Pb}$, $\mathrm{Cd}$ and $\mathrm{Zn}$ showed the same trend as dissolved $\mathrm{Cu}$ during the flood but dissolved $\mathrm{Co}$ and $\mathrm{Ni}$ had a different behaviour. Well-correlated one to the other $\left(\mathrm{R}^{2}=0.94, \mathrm{p}<0.001\right)$, they increased at the beginning of the first flood in both Huveaune and Jarret Rivers, decreased at the flow peak, but increased only in Jarret River at the beginning of the second flood.

The dissolved metal concentration as a function of the particulate metal concentration for baseflow and floods in rivers and at the outlet is given in Figure 3. In rivers, during baseflow conditions, $\mathrm{Cu}, \mathrm{Cd}$ and $\mathrm{Zn}$ (Figure 3B, 3D and 3E, respectively) were on average evenly distributed between the dissolved and particulate fractions. Lead was mainly contained in the particulate fraction (Figure 3C) and $\mathrm{Co}$ and $\mathrm{Ni}$ mainly contained in the dissolved fraction (Figure $3 \mathrm{~F}$ and $3 \mathrm{G}$, respectively). At the outlet, in baseflow conditions, dissolved concentrations were similar to those in rivers for all metals except $\mathrm{Zn}$ exhibiting higher values than in rivers. Oppositely, particulate concentrations strongly increased for all metals, due to TWW inputs (Oursel et al., 2013). During floods, concentrations of $\mathrm{Cu}, \mathrm{Cd}, \mathrm{Zn}$ and $\mathrm{Pb}$ increased in both dissolved and particulate fractions, but with an increase of the 
particulate/dissolved ratio. Concentrations of $\mathrm{Co}$ and $\mathrm{Ni}$ increased only in the particulate fraction, concentrations in the dissolved fraction remaining constant or slightly diminishing. In such flood conditions, no significant differences were observed between rivers and outlet values, indicating that the WWTP signature was overriden by the rivers water, on contrary to baseflow conditions (Oursel et al., 2013). The absence of any significant relationships between dissolved and particulate trace metals concentrations can result from repartitioning during the flood events due to the strong variation of SPM concentrations, which will further be studied using partition coefficients (see section 3.2.3).

\subsubsection{Minor and trace elements content in the particulate fraction}

No significant trend was observed for metal contents as a function of time during the flood (data not shown). Oursel et al. (2014) have shown that metals contents in the particulate fraction of Huveaune and Jarret Rivers were close to those observed in Rhône River, but when normalizing the values to Al content, particles from Huveaune and Jarret Rivers appeared to be more contaminated. Metal contents in rivers during floods (Table SI-1) were in the same order of magnitude than those observed during baseflow periods (Oursel et al., 2013) indicating the same origin of particles during baseflow and flood periods. Nevertheless, in Huveaune River, when the river flow increased, $\mathrm{Cd}$ and $\mathrm{Cr}$ contents decreased (data not shown) as it was observed in Rhône River in floods (Radakovitch et al., 2008; Ollivier et al., 2011). In Jarret River, some differences were observed, when the river flow increased, Al, Co, $\mathrm{Fe}, \mathrm{Li}, \mathrm{Mn}, \mathrm{Ni}$, and $\mathrm{V}$ contents decreased until, more or less, constant values giving an indication of the background value. On the contrary, $\mathrm{Cd}, \mathrm{Cu}, \mathrm{Pb}$ and $\mathrm{Zn}$ contents increased with increasing flow, indicating additional anthropogenic contamination. Some metal contents had good correlations one to the other, testifying similar origin and/or behaviour. In both rivers, $\mathrm{Li}, \mathrm{V}$ and $\mathrm{Fe}$ contents presented a good correlation to $\mathrm{Al}$ content $\left(\mathrm{R}^{2}\right.$ of $0.75,0.69$ and 0.50 , respectively $(\mathrm{p}<0.01)$ ), an example is given with $\mathrm{Li}$ in Figure 4A. This is consistent to the fact that these elements in rivers are known to be mainly related with rock weathering (Millot et al., 2010; Schiller and Mao, 2000). Regarding non-crustal elements, the absence of correlations with $\mathrm{Al}$ suggests that anthropogenic sources are dominant compared to natural ones. $\mathrm{Cu}$ was correlated with $\mathrm{Zn}\left(\mathrm{R}^{2}=0.81(\mathrm{p}<0.001)\right.$, Fig. $\left.4 \mathrm{~B}\right)$ and $\mathrm{Cd}$ with $\mathrm{Pb}\left(\mathrm{R}^{2}=0.74(\mathrm{p}\right.$ $<0.001)$ ) which informed about their similar source or reactivity. 


\subsection{Dynamics of elements in the mixing zone}

Sampling inside the outlet during rain events was impossible for safety reasons. As the rivers were largely the main contributors at the outlets, we supposed that metals concentrations at the outlets were close to rivers values for the 3 flood campaigns.

\subsubsection{Suspended particulate matter}

The distribution of SPM along the salinity gradient decreased with increasing salinity, showing for each flood campaign a conservative behaviour (data not shown), indicating that that freshwater SPM (min 135, $\max 195 \mathrm{mg} \mathrm{L}^{-1}$ ) were just diluted in seawater without neither significant flocculation processes, nor sediments resuspension due to the absence of tidal currents. Differences between the flood campaigns were due to the quantity of SPM discharged to the sea at the outlets. The baseflow with WWTP bypass campaign (18/04/2012) also showed a conservative behaviour, with SPM values in the range of flood events (outlet: $202 \mathrm{mg} \mathrm{L}^{-1}$ ), 9-fold higher than normal baseflow conditions (outlet: $23 \mathrm{mg} \mathrm{L}^{-1}$ in average ( $\mathrm{N}=50)$; Oursel et al., 2013).

\subsubsection{DOC and POC}

DOC variations as a function of salinity for the flood and the baseflow campaigns are given in Figure 5A. Average DOC in rivers during the 3 flood campaigns was $330 \mu \mathrm{M} \mathrm{C}$ (min 190, $\max 400$ ) for Huveaune River and $480 \mu \mathrm{M} \mathrm{C}(\min 470$, max 500) for Jarret River, so in the range of values recorded during the flood monitoring (18/09/2009). No differences were observed between on-field and in-lab filtrations neither in rivers nor in plume samples. During floods, as well as in baseflow conditions, the DOC values decreased in the plume with increasing salinity, following a conservative behaviour (Fig. 5A), as it was already observed by Pujo-Pay et al. (2006) in the Rhône River Plume. This contrasts with the non-conservative behaviour observed in the Krka River estuary (Louis et al., 2009; Sempere and Cauwet, 1995), a peculiarity due to the low DOC level in the freshwater end-member enhancing possible effects from biological activities. Oursel et al. (2013) have shown that for the by-pass campaign, DOC concentrations were higher in outlet, especially when samples were directly filtered on field. In that case, DOC showed non conservative trend along the salinity gradient for both filtrations. 
During floods, the average POC contents were 5700 and $7600 \mu \mathrm{molC} \mathrm{g}^{-1}$ for Huveaune and Jarret, respectively, values much lower than the ones encountered during baseflow (9200, 19000 and $21000 \mu \mathrm{molC} \mathrm{g}^{-1}$ on average in Huveaune, Jarret and outlet, respectively (Oursel et al., 2013)). Such differences probably reflect the contrasted source/nature of particles: terrigenous and mineral during floods, organic-rich and anthropogenic with TWW dominance during baseflow (Oursel et al., 2014). Along the salinity gradient, POC content decreased with increasing salinity but no clear trend was observed (data not shown). During the bypassed campaign, although SPM concentrations were similar to those recorded during floods, much higher POC content $\left(\sim 33000 \mathrm{mg} \mathrm{g}^{-1}\right)$ were measured at low salinity due to the predominance of organic-rich particles from untreated wastewaters.

\subsubsection{Trace elements}

For all studied trace elements, no differences were observed between on-field and in-lab filtration (data not shown) during flood campaigns, contrarily to what was observed during baseflow campaigns (Oursel et al., 2013). This means that metals were at the equilibrium between dissolved and particulate fractions when entering in the coastal waters and that desorption processes along the salinity gradient were slow with regard to mixing times. Dissolved $\mathrm{Cu}, \mathrm{Pb}, \mathrm{Cd}, \mathrm{Zn}, \mathrm{Co}, \mathrm{Ni}$ and $\mathrm{As}$ as a function of salinity for the flood and the baseflow campaigns are given in Fig. 5. Variations of element dissolved/particulate fractionation in rivers and in the salinity gradient and between campaigns were studied by plotting particulate trace elements (expressed in percent of total concentration) as a function of SPM (log scale), in comparison to the theoretical lines for given log $K d$ values (Fig. 6 and Fig. SI-1). In the following sections, the $\log K d$ values were optimized from measured data using Excel Solver subroutine, based on the following equation determined from $K d$ and mass balance equations:

$$
\frac{M_{p}}{M_{D}+M_{p}}=\frac{K_{d} S P M}{1+K_{d} S P M}
$$

$M_{P}$ and $M_{D}(\mathrm{nM})$ are respectively the particulate and dissolved concentrations of a given element, $K d$ is the optimized partition coefficient $\left(\mathrm{L} \mathrm{kg}^{-1}\right)$ and SPM the measured suspended particulate matter concentration $\left(\mathrm{kg} \mathrm{L}^{-1}\right)$. 
During floods, dissolved $\mathrm{Cu}$ decreased with increasing salinity following a quasiconservative trend (Fig. 5B), as already observed in other estuarine systems (Elbaz-Poulichet et al., 1996; Guieu et al., 1998; Shim et al., 2012). Oppositely, Cu behaviour when WWTP was by-passed and during baseflow conditions was different, showing points well above the conservative mixing line at low salinity, indicating a fast metal release from particles. During the WWTP by-pass, dissolved $\mathrm{Cu}$ at the beginning of the plume reached $350 \mathrm{nM}$, a level significantly increased when compared to the concentrations observed in the outlet during this by-pass event (170 $\mathrm{nM})$ or baseflow conditions (33nM, Oursel et al. (2013)) and more than 100-fold higher than marine end-member value (3.3 nM). Such high levels, greatly overpassing acute water quality criteria (WQC) for the protection of coastal ecosystems (WQC $_{\mathrm{Cu}} 22 \mathrm{nM}$; Durán and Beiras (2013)), could cause significant effects to living organisms. For instance, impact of untreated urban discharge on cage mussels was recently evidenced by De los Rios et al. (2013). During floods, Cu was mainly associated to particulate fraction (more than 90\%) at the outlet but its fractionation progressively evolved in the plume towards a more evenly distribution between dissolved and particulate fractions in the marine end-member (Fig. 3B). The $\mathrm{Cu}$ dissolved/particulate fractionation during the 18/09/2009 floods followed a quasi-constant $\log K d$ value in Huveaune and Jarret Rivers $\left(4.7, \mathrm{R}^{2}=0.90\right.$ $(\mathrm{N}=21)$, Fig. $6 \mathrm{~B})$, which suggests that $\mathrm{Cu}$ dynamic was more controlled by the strong changes of SPM concentrations during flood than by variations in particles affinity. This value is slightly higher than the average one observed in Rhone River (4.3, Ollivier et al., 2011). Otherwise, the $\mathrm{Cu} \log K d$ in the plume gradually evolved from $4.5\left(\mathrm{SPM}>100 \mathrm{mg} \mathrm{L}^{-1} ; \mathrm{R}^{2}=\right.$ $0.73(\mathrm{~N}=13))$ to $5.3\left(\mathrm{SPM}<20 \mathrm{mg} \mathrm{L}^{-1} ; \mathrm{R}^{2}=0.53(\mathrm{~N}=10)\right)$ with increasing salinity, a behaviour already observed by Turner et al. (2002), which could imply a repartitioning onto particles of higher affinity despite an apparently conservative behaviour (Fig. 5B). Although more dispersed, data points corresponding to baseflow conditions (22/03/2011) showed similar trend (Fig. 6B), exhibiting higher $\log K d$ values than during floods and reaching the highest values ( 5.7) at the lowest SPM concentrations. Ollivier et al. (2011) also observed higher $\log K d$ in baseflow than in floods in Rhone River. Similar phenomena was attributed by Cobelo-Garcia et al. (2004) to different origin of SPM: (1) detrital material from soil weathering, (2) organic material from biota and urban/industrial effluents, the former being predominant during flood events together with an increase of sand material. In the present 
case, the significant correlation between main detrital components (e.g. Al-Fe, $\mathrm{R}^{2}=0.91$ $(\mathrm{N}=29)$ ) observed for flood particles, and the higher POC (see part 3.2.2) content in baseflow particles confirmed such hypothesis. However, during the 18/04/2012 by-pass event, a lower $\log K d$ related to a significant desorption (Fig. 5B) was observed at low salinity ( 4.1), which suggests that sorption properties of untreated wastewater particles are more sensitive to salinity, despite a very high organic carbon content.

\subsubsection{2. $\mathrm{Pb}$}

During floods, the decrease of dissolved $\mathrm{Pb}$ with increasing salinity was non-conservative with points slightly above the conservative line at salinity between 15 and 35 (Fig. 5C), when in baseflow conditions points were above the conservative mixing line at low salinity, especially during the WWTP by-pass event. Both conditions indicate desorption of $\mathrm{Pb}$ from particles, but the observed differences between flood and baseflow conditions could result from different desorption kinetic, particles nature/reactivity and/or mixing time. This contrasts with conservative behaviour of dissolved $\mathrm{Pb}$ observed in Rhône River plume (Elbaz-Poulichet el al., 1996) or in the Gironde estuary (Kraepiel et al., 1997). At any period, Pb was mainly in the particulate fraction (more than 95\%) at the outlet and progressively evolved in the plume towards a lower particulate/dissolved fractionation (Fig. 3C). As for $\mathrm{Cu}$, the $\mathrm{Pb}$ dissolved/particulate fractionation during the 18/09/20109 floods followed a quasi-constant $\log K d$ value in Huveaune and Jarret Rivers $\left(6.1, \mathrm{R}^{2}=0.89(\mathrm{~N}=20)\right.$, Fig. 6F). The value was higher than observed for $\mathrm{Cu}$, which highlights a stronger affinity for particles, as already observed in previous studies (e.g. Cobelo-Garcia, 2004; Ollivier et al., 2011). In the salinity gradient, the $\log K d$ values slightly decreased $\left(5.7, \mathrm{R}^{2}=0.88(\mathrm{~N}=28)\right)$; some points had low values ( 5.1) likely corresponding to marine-born particles. Similarly to $\mathrm{Cu}$, during the 18/04/2012 by-pass event, the significant $\mathrm{Pb}$ desorption observed at low salinity (Fig. 5C) resulted in much lower $\log K d$ values (down to $\sim 4.5$ ). In baseflow conditions (22/03/2011), the $\log K d$ values in the salinity gradient were also lower $\left(5.5, \mathrm{R}^{2}=0.78(\mathrm{~N}=9)\right)$ than those observed during floods.

\subsubsection{3. $C d$}

During the 25/10/2011 flood and in baseflow conditions, dissolved Cd remained quite constant with increasing salinity showing a quasi-conservative behaviour as it was observed 
in other study (Michel et al., 2000). During the 2 other flood campaigns and the WWTP bypass event, points far above the theoretical conservative mixing line indicated a release of $\mathrm{Cd}$ from particles (Fig. 5D). Such desorption is well documented and is related to the formation of stable and soluble chlorocomplexes in the dissolved fraction (Dai and Martin, 1995; ElbazPoulichet et al., 1987; Audry et al., 2007; Waeles et al., 2008). This process could partly explain that $\mathrm{Cd}$ was mainly found in the particulate fraction (more than 94\%) during flood events at the outlet and mainly switched as dissolved at the end of the plume (Fig. 3D). Accordingly, if the Cd dissolved/particulate log $K d$ during the 18/09/20109 floods remained quasi-constant in Huveaune and Jarret Rivers $\left(\sim 4.7, \mathrm{R}^{2}=0.72(\mathrm{~N}=22)\right.$, Fig. 6D), it decreased in the plume down to 4.5 (25/10/2011 and 21/05/2012 campaigns) and $\sim 4.1(28 / 11 / 2012$ campaign), in relation to a significant Cd desorption (Fig. 5D), as already evidenced in other environment (e.g. Turner et al., 2004). In baseflow conditions (22/03/2011), higher log $K d$ values $\left(5.2, \mathrm{R}^{2}=0.75(\mathrm{~N}=12)\right)$ could be due to a different affinity for particles mostly originating from TWW (Oursel et al., 2013).

\subsubsection{4. $\mathrm{Zn}$}

During two floods (25/10/2011 and 21/05/2012) and in baseflow conditions, dissolved Zn decreased with increasing salinity with a quasi-conservative behaviour (Fig. 5E) as it was observed in the Gironde estuary (Michel et al., 2000). During the 28/11/2012 flood, points above the mixing line indicated a release of $\mathrm{Zn}$ from particles at low salinity as previously reported for the Scheldt estuary (Zwolsman et al., 1997) and Rhône River plume (ElbazPoulichet et al., 1996). During the WWTP by-pass event, points situated far below the mixing line at salinity lower than 15 indicated an adsorption on particles. The particulate/dissolved fractionation of $\mathrm{Zn}$ remained quite constant along the salinity gradient during flood events, but increased in baseflow conditions (Fig. 3E). However, during floods, even if $\mathrm{Zn}$ was mainly found in the particulate fraction (more than 90\%) at the outlet, dissolved $\mathrm{Zn}$ concentrations can be 3-fold higher than $\mathrm{WQC}_{\mathrm{Zn}}$ value (126 nM, Durán and Beiras (2013)) and even more during WWTP by-pass (4-fold higher). Zn dissolved/particulate log $K d$ (Fig. SI-1A) followed no clear pattern, neither from one campaign to another nor within the plume.

\subsubsection{Co}


During floods, dissolved Co exhibited a non-conservative behaviour with points above the mixing line (Fig. 5F), indicating Co release from particles at low salinity as it was observed in the Sagami and Wasaka estuaries (Takata et al., 2010) and in the Hudson River estuary (Tovar-Sánchez et al., 2004). In baseflow conditions and during the WWTP by-pass event, dissolved Co showed a quasi-conservative behaviour. Particulate Co was the dominant fraction during floods in outlet (more than 90\%), on contrary to baseflow conditions (Fig. 3F). The Co dissolved/particulate log $K d$ during the 18/09/2009 floods remained stable $\left(4.8, \mathrm{R}^{2}=\right.$ 0.96 (N=22), Fig. SI-1B) in Huveaune and Jarret Rivers. It decreased at low salinity down to $\sim 4.4$ for the 18/09/2009 floods and to $\sim 3.5$ for the 18/04/2012 by-pass event. As noticed for $\mathrm{Cu}$ and $\mathrm{Cd}$, higher $\log K d(\sim 5)$ were observed during baseflow.

\subsubsection{6. $\mathrm{Ni}$}

In any conditions, dissolved $\mathrm{Ni}$ decreased with increasing salinity with a nonconservative behaviour, with points located above the mixing line indicating Ni release from particles (Fig. 5G). However, a conservative behaviour was commonly observed in the $\mathrm{Ob}$ and Yenisey estuaries (Dai and Martin, 1995), in Rhône River plume (Elbaz-Poulichet et al., 1996) and in the Gironde estuary (Michel et al., 2000). As Ni was mainly in the dissolved fraction in baseflow conditions and in the particulate fraction in floods (more than 80\%), the particulate/dissolved fractionation of $\mathrm{Ni}$ increased in the plume in baseflow conditions, but decreased during flood events (Fig. 3G). The variations of Ni partitioning (Fig. SI-1C) followed similar trends than Co: stable value of $\log K d$ in rivers during the 18/09/2009 floods $\left(4.4, \mathrm{R}^{2}=0.98(\mathrm{~N}=22)\right)$, slight decrease at low salinity down to $\sim 4.1$ for floods and to $\sim 3.8$ for the by-pass event, higher values up to $\sim 6$ during baseflow.

\subsubsection{As}

Whatever the conditions, dissolved As increased with increasing salinity showing a conservative behaviour (Fig. 5H) as it was reported in the Gironde estuary (Michel et al., 2000) or in the Krka River estuary (Seyler and Martin., 1991). This conservative behaviour contrasted with a non-conservative behaviour observed for instance in the Penzé estuary (Vandenhecke et al., 2010). In this last study, the non-conservative behaviour was ascribed to inputs of dissolved As, probably from sediments (Vandenhecke et al., 2010), a mechanism not expected in our case considering the surface extension of the plume. In the Krka River 
estuary, dissolved As concentration was lower in Krka River than in the Mediterranean Sea due to a low contamination of the Krka River basin (Seyler and Martin., 1991). Total dissolved As was observed between 12.4 and $18.9 \mathrm{nM}$ in the Adriatic Sea (Pettine et al., 1997), slightly lower than in this study (21 nM, Table 1). In baseflow period, in rivers and in outlet, dissolved As form was dominant (in higher proportion in outlet) whereas during floods, particulate fraction dominated (70-80\%). Finally in the marine end-member, dissolved As was in higher proportions compared to particulate one. Such variations can reasonably be explained considering the dissolved/particulate fractionation (Fig. SI-1D): during floods, in both rivers and salinity gradient, $\log K d$ exhibited constant values $\left(3.9, \mathrm{R}^{2}=0.94(\mathrm{~N}=31)\right)$, significantly lower than the ones observed for other studied metals; low values for the by-pass event $\left(3.5, \mathrm{R}^{2}=0.99(\mathrm{~N}=7)\right)(18 / 04 / 2012)$; higher values up to 4.1 during baseflow.

\subsection{Remobilization experiment}

The differences between the outlet baseflow sample and the artificial flood outlet sample were the following (Fig. 6A, 6C, 6E and SI-2A to SI-2D, open $v$ s. close symbols at $\mathrm{S}=0$ ). For all studied metals but As, dissolved concentrations were higher in the artificial flood sample than in the outlet baseflow sample, indicating a partial desorption from particles: from $20 \%$ (Ni) to 550-600\% ( $\mathrm{Pb}$ and $\mathrm{Cu}$ ). However, the particulate fraction remained dominant (83 to 98\%) for all the studied elements, a similar situation as encountered in field samples from rivers and outlet during flood events. Copper, $\mathrm{Cd}$ and $\mathrm{Pb}$ exhibited three contrasted behaviors (Fig. 6), according to the range of salinity where the maximal desorption occurred. The DOC (data not shown) showed a conservative behavior with salinity, in agreement with field data (Fig. 5A). Conversely, all the studied trace elements were desorbed from SPM. As observed in many other estuarine systems, such non-conservative behavior resulted from a complex interplay of various parameters and processes such as: intrinsic affinity of trace metals $v s$. flood particles $(K d)$, SPM concentration, kinetic of association/dissociation reactions, ionic strength, $\mathrm{pH}$ changes, competition of major ions (cations and anions) toward trace metals and particles binding site, ... . Considering the deviation from the conservative line, $\mathrm{Cd}$ was the most intensively released element (Fig. 6B), whereas As was the less released (Fig. SI-2D). The shape of desorption curves showed that the maximum absolute release occurred at low salinity for $\mathrm{Cu}, \mathrm{Zn}$ and $\mathrm{Ni}$, at low to mid-salinity for As, mid-salinity for $\mathrm{Cd}$ and $\mathrm{Co}$, and at high salinity for $\mathrm{Pb}$. However, when expressed in term of percent of released metal (i.e. the fraction of metal released from SPM), the maximum release was in all cases obtained for the 
longest contact time $(24 \mathrm{~h})$ at the highest salinity $(\mathrm{S}=30)$; it varied from $4 \%(\mathrm{~Pb})$ to $25 \%(\mathrm{Cd}$ and $\mathrm{Cu}$ ) of initial particulate metal content. These discrepancies between elements resulted from different affinities for particles $(\log K d$ ) and effect of salinity. No element but Co has reached its desorption isotherm plateau after $24 \mathrm{~h}$ of contact time (data not shown), which suggested slow kinetics. The restricted number of data, however, prevents modelling the kinetics of metal/particles affinity. In order to compare this experiment with field conditions, experiment results corresponding to $15 \mathrm{~min}$ and $24 \mathrm{~h}$ of contact time were plotted in terms of metals dissolved/particulate fractionation vs. SPM concentration (Fig. 6 and SI-1). Consistently with field patterns, $\mathrm{Pb}$ and As depicted the highest $(\log K d>5)$ and lowest $(\log$ $K d<4)$ values, but $\log K d$ experimental values were slightly lower than flood events field values. That may be due to a higher proportion of large particles having weak affinity for trace element in the flood deposit sample compared to SPM in floods (Benoit and Rozan, 1999).

Such results, gathering field data and lab experiments, allowed a better assessment of metals behaviour and fate in the studied environment. Compared to the results from another experiments performed by Oursel et al. (2013) to described baseflow conditions, they suggested that during floods, sorption/desorption mechanisms in the salinity gradient are slower than in baseflow conditions. This is likely due to differences in SPM: particles are mostly terrigeneous during flood and anthropogenic with a TWW signature during baseflow (Oursel et al., 2014). Slower kinetics in the plume during flood events, however, may result in subsequent desorption after sediment deposition, amplifying a potential impact on benthic organisms.

\section{Concluding remarks}

During rain periods, the dissolved and particulate trace metal temporal dynamics in rivers were flood, river and element dependent. The studied system was highly dynamic and rapidly answered from the beginning of rain, which is typical of small Mediterranean rivers, especially when the water catchment is urbanized, requiring an adapted monitoring strategy. Metals contamination was mainly brought by the particulate fraction that originated from the leaching of impervious surfaces and soil erosion. The dissolved/particulate fractionation of a given trace element expressed in $\log K d$ followed in rivers quasi-constant values during floods; $\mathrm{Pb}$ and As had respectively the highest ( 6.1) and the lowest ( 3.9) $\log K d$ values. For all studied elements but $\mathrm{Pb}, \log K d$ values were lower in floods that during baseflow, 
indicating lower affinities for particles; the high values of particulate trace element concentration during floods mostly resulted therefore from high SPM concentrations.

During flood conditions, the average concentrations of dissolved and particulate metals at the outlet were in the same range than in rivers, indicating that the WWTP signature, predominant during baseflow, was diluted and masked during floods. As floods brought to the sea around 94\% of the annual SPM discharge, differences in total trace element contents between floods and baseflow had little weight on the annual particulate trace element fluxes that were mostly driven by rain events, as already observed in similar Mediterranean rivers. Oppositely, annual dissolved metals fluxes were likely mainly brought during baseflow periods, due to the strong influence of treated/untreated wastewaters inputs. An accurate evaluation of the global pollutants discharge to the coastal zone, however, would require a continuous monitoring of inputs.

When discharged to the sea, most of the studied elements presented a non-conservative behaviour along the salinity gradient due to desorption from particles, especially at highest salinity. The apparent inconsistency between floods was likely due to temporal variations of element-bearing phases at the outlet, depending on element dissolved/particulate partitioning in freshwater before discharge.

The laboratory remobilisation results were consistent with field data and suggested that element desorption from particles is slower than sedimentation. With regard to heavy particles, it results in a potential impact of the sediment on benthic organisms and a possible further desorption after sediment resuspension events. With regard to light particles, it results in a possible desorption during offshore transport.

The WWTP by-pass in baseflow conditions resulted in higher contamination of the dissolved phase (e.g. close to $350 \mathrm{nM}$ of dissolved $\mathrm{Cu}$ ), due to weaker affinity of untreated wastewater particles for the studied trace elements. Discharge of these untreated effluents leads to trace metals levels significantly overpassing acute water quality criteria for the protection of coastal ecosystems (e.g. $\mathrm{WQC}_{\mathrm{Cu}} 22 \mathrm{nM}$ ). Consequently, the potential impact of such strongly-polluted events on coastal organisms may result from (1) direct exposure to desorbed metals due to salinity effects and (2) ingestion of organic-rich wastewater particles and associated pollutants by zooplankton and further transfer to food web (Bănaru et al., 2014). Further studies, however, are needed to investigate the impact of such large agglomeration discharge on coastal micro- and macro-organisms in comparison to other sources (large rivers, aerosols). 


\section{Acknowledgments}

The authors would like to thank all the persons who participated at sampling campaigns, for their help in samples preparation. The authors would also like to thank "Météo-France" (Y. Bidet), "MIO" (C. Yohia), "SERAM" (A. Queau, F. Jonot), and "DEA" of Marseille city (Z. Djelalli, S. Barde) for access to the study site, material installation, flow and rainfall values, meteorological data at the Marseille observatory station ("GIRAC-PACA" project). The authors would also like to thank D.H. Dang for dissolved As analysis.

This collaborative work and B. Oursel Ph.D. were financially supported by the "ANR CES MARSECO" and the "GIRAC-PACA" projects (FUI, TPM, Région Provence Alpes Côte d'Azur); this study was part of the "MerMex-WP3-C3A" and international "IMBER" projects. We thanked the two anonymous reviewers for their constructive and helpful comments.

\section{Bibliography}

Ammann, A.A., Rüttimann, T.B., Bürgi, F., 2000. Simultaneous determination of TOC and $\mathrm{TNb}$ in surface and wastewater by optimised high temperature catalytic combustion. Water Res. 34, 3573-3579.

Audry, S., Blanc, G., Schäfer, J., Guérin, F., Masson, M., Robert, S., 2007. Budgets of $\mathrm{Mn}, \mathrm{Cd}$ and $\mathrm{Cu}$ in the macrotidal Gironde estuary (SW France). Mar. Chem. 107, 433-448.

Bănaru, D., Carlotti, F., Grégori, G., Neffati, N., Harmelin-Vivien, M., 2014. Seasonal variation of stable isotope ratios of size-fractionated zooplankton in the Bay of Marseille (NW Mediterranean Sea). J. Plankton Res. 36, 145-156.

Bay, S.M., Zeng, E.Y., Lorenson, T.D., Tran, K., Alexander, C., 2003. Temporal and spatial distributions of contaminants in sediments of Santa Monica Bay, California. Mar. Environ. Res. 56, 255-276.

Benoit, G., Rozan, T.F., 1999. The influence of size distribution on the particle concentration effect and trace metal partitioning in rivers. Geochim. Cosmochim. Acta 63, 113-127.

Bothner, M.H., Casso, M.A., Rendigs, R.R., Lamothe, P.J., 2002. The effect of the new Massachusetts Bay sewage outfall on the concentrations of metals and bacterial spores in nearby bottom and suspended sediments. Mar. Pollut. Bull. 44, 1063-1070. 
Boyle, E.A., Edmond, J.M., Sholkovitz, E.R., 1977. The mechanism of iron removal in estuaries. Geochim. Cosmochim. Acta 41, 1313-1324.

Callahan, J., Dai, M., Chen, R.F., Li, X., Lu, Z., Huang, W., 2004. Distribution of dissolved organic matter in the Pearl River Estuary, China. Mar. Chem. 89, 211-224.

Cobelo-Garcia, A., Prego, R., Labandeira, A., 2004. Land inputs of trace metals, major elements, particulate organic carbon and suspended solids to an industrial coastal bay of the NE Atlantic. Wat. Res. 38, 1753-1764.

Dai, M.-H., Martin, J.-M., 1995. First data on trace metal level and behaviour in two major Arctic river-estuarine systems ( $\mathrm{Ob}$ and Yenisey) and in the adjacent Kara Sea, Russia. Earth Planet. Sc. Lett. 131, 127-141.

Dang, D.H., Tessier, E., Lenoble, V., Durrieu, G., Omanović, D., Mullot, J.-U., Pfeifer, H.R., Mounier, S., Garnier, C., 2014. Key parameters controlling arsenic dynamics in coastal sediments: an analytical and modelling approach. Mar. Chem. 161, 34-46.

Dassenakis, M., Scoullos, M., Gaitis, A., 1997. Trace metals transport and behaviour in the Mediterranean estuary of Acheloos river. Mar. Pollut. Bull. 34, 103-111.

De los Ríos, A., Pérez, L., Ortiz-Zarragoitia, M., Serrano, T., Barbero, M.C., EchavarriErasun, B., Juanes, J.A., Orbea, A., Cajaraville, M.P., 2013. Assessing the effects of treated and untreated urban discharges to estuarine and coastal waters applying selected biomarkers on caged mussels. Mar. Pollut. Bull. 77, 251-265.

Durán, I., Beiras, R., 2013. Ecotoxicologically based marine acute water quality criteria for metals intended for protection of coastal areas. Sci. Total Environ. 463-464, 446-453.

Elbaz-Poulichet, F., Martin, J.M., Huang, W.W., Zhu, J.X., 1987. Dissolved Cd behaviour in some selected french and chinese estuaries. Consequences on $\mathrm{Cd}$ supply to the ocean. Mar. Chem. 22, 125-136.

Elbaz-Poulichet, F., Garnier, J.-M., Guan, D.M., Martin, J.-M., Thomas, A.J., 1996. The conservative behaviour of trace metals $(\mathrm{Cd}, \mathrm{Cu}, \mathrm{Ni}$ and $\mathrm{Pb})$ and $\mathrm{As}$ in the surface plume of stratified estuaries: example of the Rhône River (France). Estuar. Coast. Shelf S. 42, 289-310.

Elbaz-Poulichet, F., 2005. River inputs of metals and arsenic, in: Saliot, A. (Ed.), The Mediterranean Sea. Springer Berlin Heidelberg, pp. 211-235.

Gonzalez, H., Pomares, M., Ramirez, M., Torres, I., 1999. Heavy metals in organisms and sediments from the discharge zone of the submarine sewage outfall of Havana city, Cuba. Mar. Pollut. Bull. 38, 1048-1051. 
Guieu, C., Martin, J.M., Tankéré, S.P.C., Mousty, F., Trincherini, P., Bazot, M., Dai, M.H., 1998. On trace metal geochemistry in the Danube River and Western Black Sea. Estuar. Coast. Shelf S. 47, 471-485.

Gupta, A., Rai, D., Pandey, R., Sharma, B., 2009. Analysis of some heavy metals in the riverine water, sediments and fish from river Ganges at Allahabad. Environ Monit Assess $157,449-458$.

Infoclimat, 2014. http://www.infoclimat.fr/climatologie-07650-marseille-marignane.html. Last access 2014/02/13.

Jany, C., Cossa, D. , Djelalli, Z., Garnier, C., Mounier, S., Pairaud, I., Sauzade, D., Thouvenin, B., Zebracki, M., 2012. METROC : Evaluation des apports de contaminants chimiques de la métropole marseillaise au milieu marin, Rapport Ifremer RST.ODE/LER/PAC/12-02 - Agence de l'eau AERM\&C, 140 p.

Kraepiel, A.M.L., Chiffoleau, J.-F., Martin, J.-M., Morel, F.M.M., 1997. Geochemistry of trace metals in the Gironde estuary. Geochim. Cosmochim. Ac. 61, 1421-1436.

Le Masson, J., 1997. Mesures de pollution par temps de pluie à Marseille. Rapport SERAM.

Lenoble, V., Omanović, D., Garnier, C., Mounier, S., Đonlagić, N., Le Poupon, C., Pižeta, I., 2013. Distribution and chemical speciation of arsenic and heavy metals in highly contaminated waters used for health care purposes (Srebrenica, Bosnia and Herzegovina). Sci. Total Environ. 443, 420-428.

López-Flores, R.o., Quintana, X.D., Salvadó, V., Hidalgo, M., Sala, L., Moreno-Amich, R., 2003. Comparison of nutrient and contaminant fluxes in two areas with different hydrological regimes (Empordà Wetlands, NE Spain). Water Res. 37, 3034-3046.

Lorrain, A., Savoye, N., Chauvaud, L., Paulet, Y.-M., Naulet, N., 2003. Decarbonation and preservation method for the analysis of organic $\mathrm{C}$ and $\mathrm{N}$ contents and stable isotope ratios of low-carbonated suspended particulate material. Anal. Chim. Acta 491, 125-133.

Louis, Y., Garnier, C., Lenoble, V., Mounier, S., Cukrov, N., Omanović, D., Pižeta, I., 2009. Kinetic and equilibrium studies of copper-dissolved organic matter complexation in water column of the stratified Krka River estuary (Croatia). Mar. Chem. 114, 110-119.

Martínez-Casasnovas, J.A., Ramos, M.C., Ribes-Dasi, M., 2002. Soil erosion caused by extreme rainfall events: mapping and quantification in agricultural plots from very detailed digital elevation models. Geoderma 105, 125-140. 
Matthai, C., Birch, G.F., Bickford, G.P., 2002. Anthropogenic trace metals in sediment and settling particulate matter on a high-energy continental shelf (Sydney, Australia). Mar. Environ. Res. 54, 99-127.

Michel, P., Boutier, B., Chiffoleau, J.F., 2000. Net fluxes of dissolved arsenic, cadmium, copper, zinc, nitrogen and phosphorus from the Gironde Estuary (France): seasonal variations and trends. Estuar. Coast. Shelf S. 51, 451-462.

Millot, R., Vigier, N., Gaillardet, J., 2010. Behaviour of lithium and its isotopes during weathering in the Mackenzie Basin, Canada. Geochim. Cosmochim. Acta 74, 3897-3912.

Ni, H.-G., Lu, F.-H., Luo, X.-L., Tian, H.-Y., Zeng, E.Y., 2008. Riverine inputs of total organic carbon and suspended particulate matter from the Pearl River Delta to the coastal ocean off South China. Mar. Pollut. Bull. 56, 1150-1157.

Nicolau, R., Lucas, Y., Merdy, P., Raynaud, M., 2012. Base flow and stormwater net fluxes of carbon and trace metals to the Mediterranean Sea by an urbanized small river. Water Research. 46, 6625-6647.

Ollivier, P., Radakovitch, O., Hamelin, B., 2011. Major and trace element partition and fluxes in the Rhône River. Chem. Geol. 285, 15-31.

Omanović D., Kwokal Z., Goodwin A., Lawrence A., Banks C.E., Compton R.G., S., K., 2006. Trace metal detection in Šibenik Bay, Croatia: cadmium, lead and copper with anodic stripping voltammetry and manganese via sonoelectrochemistry. A case study. Journal of the Iranian Chemical Society 3, 128-139.

Oursel, B., Garnier, C., Durrieu, G., Mounier, S., Omanović, D., Lucas, Y., 2013. Dynamics and fates of trace metals chronically input in a Mediterranean coastal zone impacted by a large urban area. Mar. Pollut. Bull. 69, 137-149.

Oursel, B., Garnier, C., Pairaud, I., Omanović, D., Durrieu, G., Syakti., A.D., Le Poupon, C., Thouvenin, B., Lucas, Y., 2014. Behaviour and fate of urban particles in coastal waters: settling rate, size distribution and metals contamination characterization. Estuar. Coast. Shelf S. $138,14-26$.

Pettine, M., Mastroianni, D., Camusso, M., Guzzi, L., Martinotti, W., 1997. Distribution of As, Cr and V species in the Po-Adriatic mixing area, (Italy). Mar. Chem. 58, 335-349.

Pujo-Pay, M., Conan, P., Joux, F., Oriol, L., Naudin, J-J., Cauwet, G., 2006. Impact of phytoplankton and bacterial production on nutrient and DOM uptake in the Rhône River plume (NW Mediterranean). Mar. Ecol-Prog. Ser. 315, 43-54. 
Radakovitch, O., Roussiez, V., Ollivier, P., Ludwig, W., Grenz, C., Probst, J.-L., 2008. Input of particulate heavy metals from rivers and associated sedimentary deposits on the Gulf of Lion continental shelf. Estuar. Coast. Shelf S. 77, 285-295.

Raimbault, P., Durrieu de Madron, X., 2003. Research activities in the Gulf of Lion (NW Mediterranean) within the 1997-2001 PNEC project. Oceanologica Acta 26, 291-298.

Shafer, M.M., Overdier, J.T., Hurley, J.P., Armstrong, D., Webb, D., 1997. The influence of dissolved organic carbon, suspended particulates, and hydrology on the concentration, partitioning and variability of trace metals in two contrasting Wisconsin watersheds (U.S.A.). Chem. Geol. 136, 71-97.

Sempere, R., Cauwet, G., 1995. Occurrence of organic colloids in the stratified estuary of the Krka River (Croatia). Estuar. Coast. Shelf S. 40, 105-114.

Seyler, P., Martin, J.M., 1991. Arsenic and selenium in a pristine river-estuarine system: the Krka (Yugoslavia). Mar. Chem. 34, 137-151.

Shiller, A.M., 1997. Dissolved trace elements in the Mississippi River: seasonal, interannual, and decadal variability. Geochim. Cosmochim. Ac. 61, 4321-4330.

Shiller, A.M., Mao, L., 2000. Dissolved vanadium in rivers: effects of silicate weathering. Chem. Geol. 165, 13-22

Shim, M.-J., Swarzenski, P.W., Shiller, A.M., 2012. Dissolved and colloidal trace elements in the Mississippi River delta outflow after Hurricanes Katrina and Rita. Cont. Shelf. Res. 42, 1-9.

Takata, H., Aono, T., Tagami, K., Uchida, S., 2010. Processes controlling cobalt distribution in two temperate estuaries, Sagami Bay and Wakasa Bay, Japan. Estuar. Coast. Shelf S. 89, 294-305.

Tao, S., 1998. Spatial and temporal variation in DOC in the Yichun River, China. Water Res. 32, 2205-2210.

Tessier, E., Garnier, C., Mullot, J.-U., Lenoble, V., Arnaud, M., Raynaud, M., Mounier, S., 2011. Study of the spatial and historical distribution of sediment inorganic contamination in the Toulon bay (France). Mar. Pollut. Bull. 62, 2075-2086.

Thill, A., Moustier, S., Garnier, J.-M., Estournel, E., Naudin, J.-J., Bottero, J.-Y., 2001. Evolution of particle size and concentration in the Rhone river mixing zone: influence of salt flocculation. Cont. Shelf Res. 21, 2127-2140.

Tovar-Sánchez, A., Sañudo-Wilhelmy, S.A., Flegal, A.R., 2004. Temporal and spatial variations in the biogeochemical cycling of cobalt in two urban estuaries: Hudson River Estuary and San Francisco Bay. Estuar. Coast. Shelf S. 60, 717-728. 
Turner, A., Martino, M., Le Roux, S.M., 2002. Trace Metal Distribution Coefficients in the Mersey Estuary, UK: Evidence for Salting out of Metal Complexes. Environ. Sci. Technol. 36, 4578-4584.

Turner, A., Millward, G.E., Le Roux, S.M., 2004. Significance of oxides and particulate organic matter in controlling trace metal partitioning in a contaminated estuary. Mar. Chem. 88, 179-192.

Vandenhecke, J., Waeles, M., Cabon, J.-Y., Garnier, C., Riso, R.D., 2010. Inorganic arsenic speciation in the waters of the Penzé estuary (NW France): seasonal variations and fluxes to the coastal area. Estuar. Coast. Shelf S. 90, 221-230.

Waeles, M., Riso, R.D., Le Corre, P., 2005. Seasonal variations of cadmium speciation in the Penzé estuary, NW France. Estuar. Coast. Shelf S. 65, 143-152.

Waeles, M., Tanguy, V., Lespes, G., Riso, R.D., 2008. Behaviour of colloidal trace metals $(\mathrm{Cu}, \mathrm{Pb}$ and $\mathrm{Cd})$ in estuarine waters: An approach using frontal ultrafiltration (UF) and stripping chronopotentiometric methods (SCP). Estuar. Coast. Shelf S. 80, 538-544.

Wei, Q., Zhu, G., Wu, P., Cui, L., Zhang, K., Zhou, J., Zhang, W., 2010. Distributions of typical contaminant species in urban short-term storm runoff and their fates during rain events: A case of Xiamen City. Journal of Environmental Sciences 22, 533-539.

Wu, Y., Bao, H.-Y., Unger, D., Herbeck, L.S., Zhu, Z.-Y., Zhang, J., Jennerjahn, T.C., 2013. Biogeochemical behaviour of organic carbon in a small tropical river and estuary, Hainan, China. Cont. Shelf. Res. 57, 32-43.

Zwolsman, J.J.G., Van Eck, B.T.M., Van Der Weijden, C.H., 1997. Geochemistry of dissolved trace metals (cadmium, copper, zinc) in the Scheldt estuary, southwestern Netherlands: Impact of seasonal variability. Geochim. Cosmochim. Ac. 61, 1635-1652. 


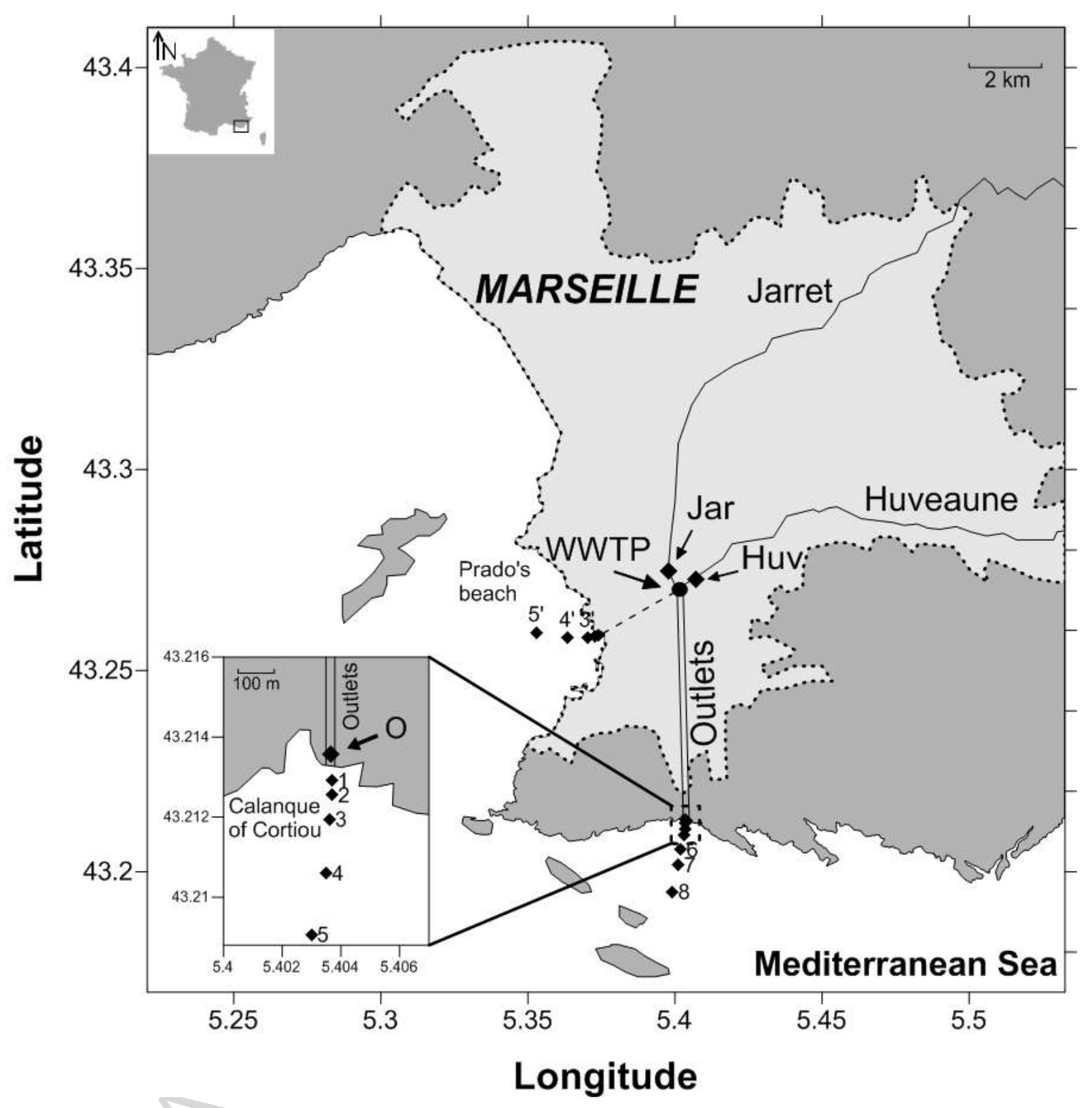

Figure 1 
Oursel et al. Fig. 2
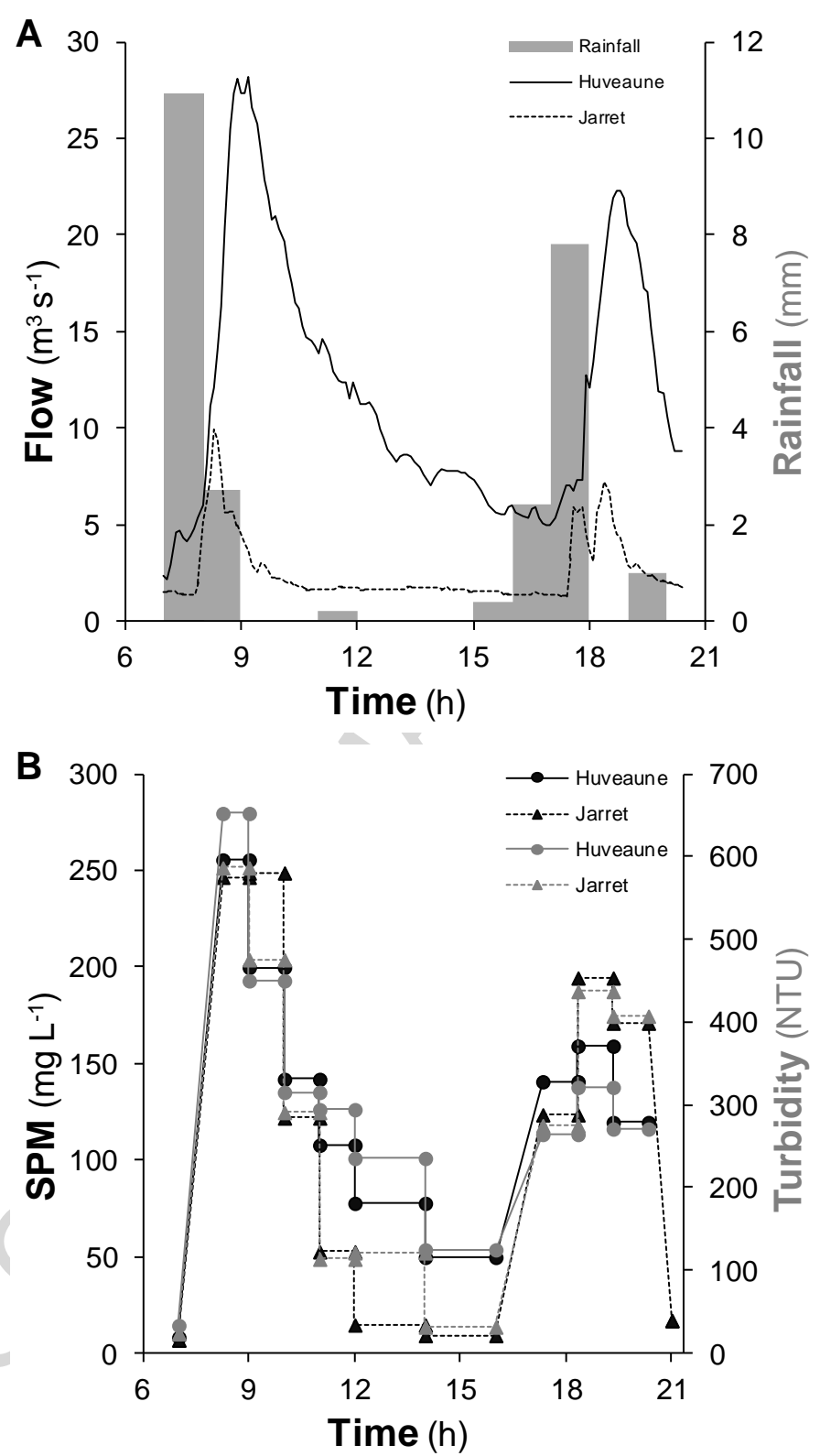


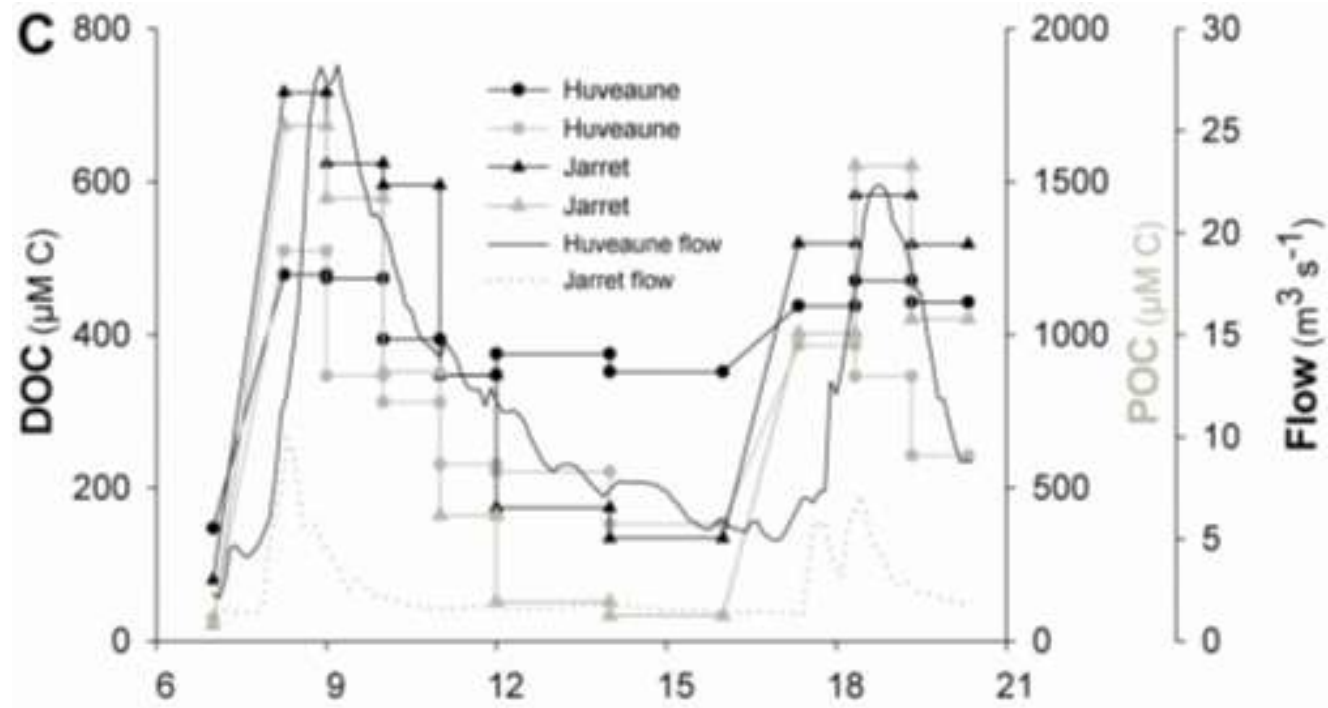

Time (h)

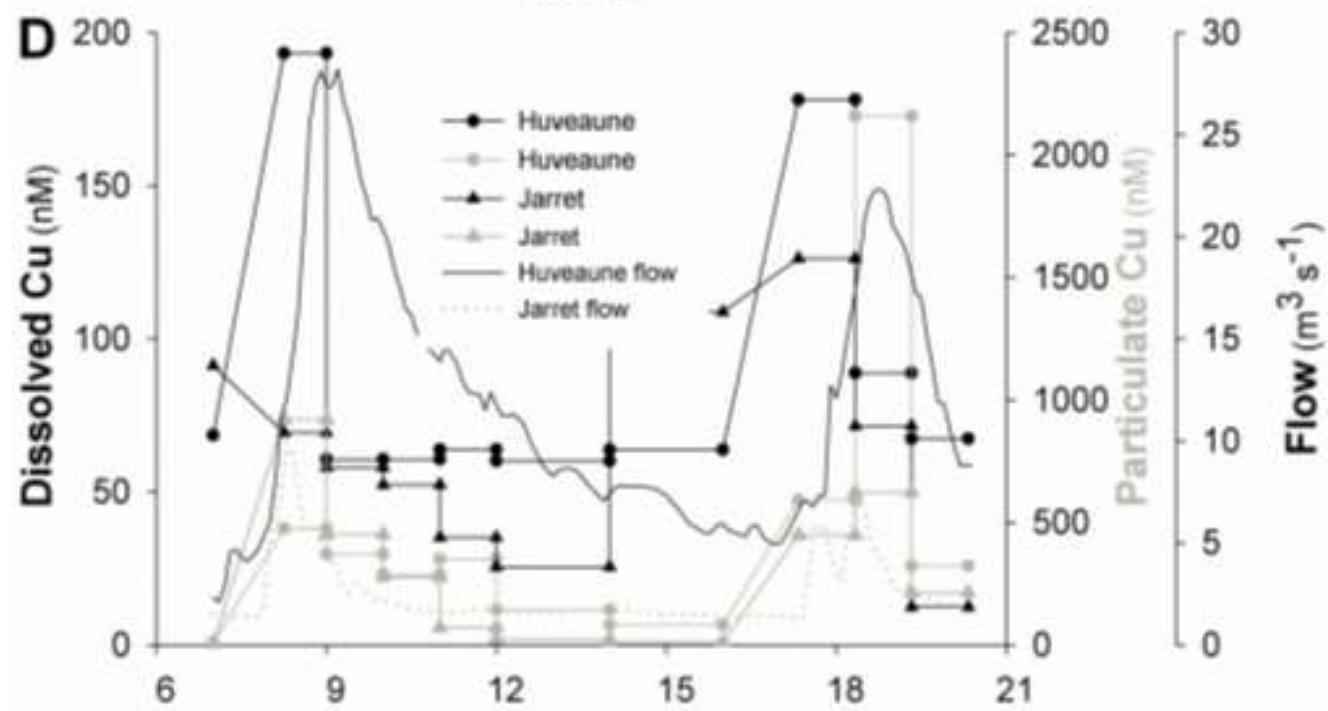

Time (h) 
Oursel et al. Fig. 3
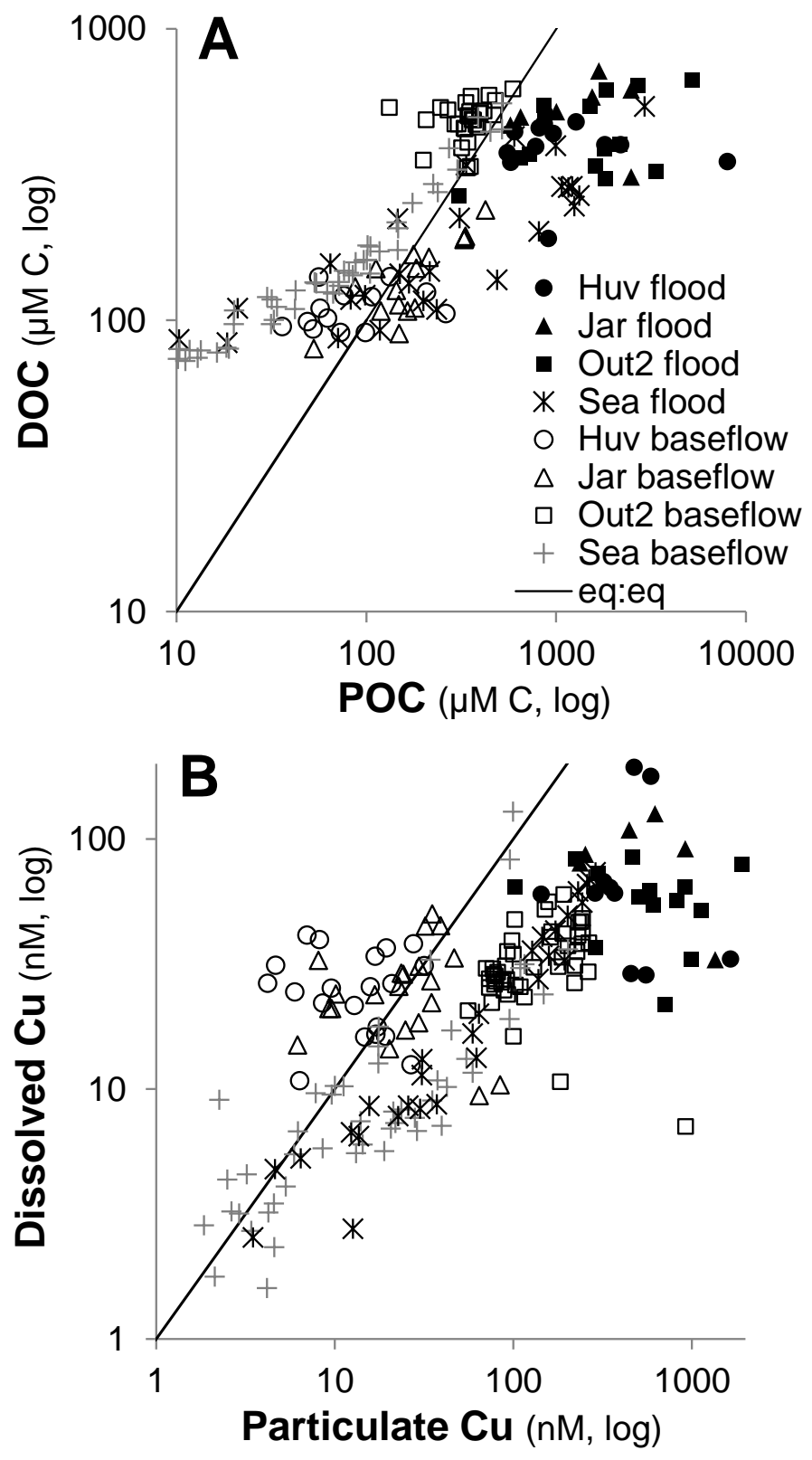

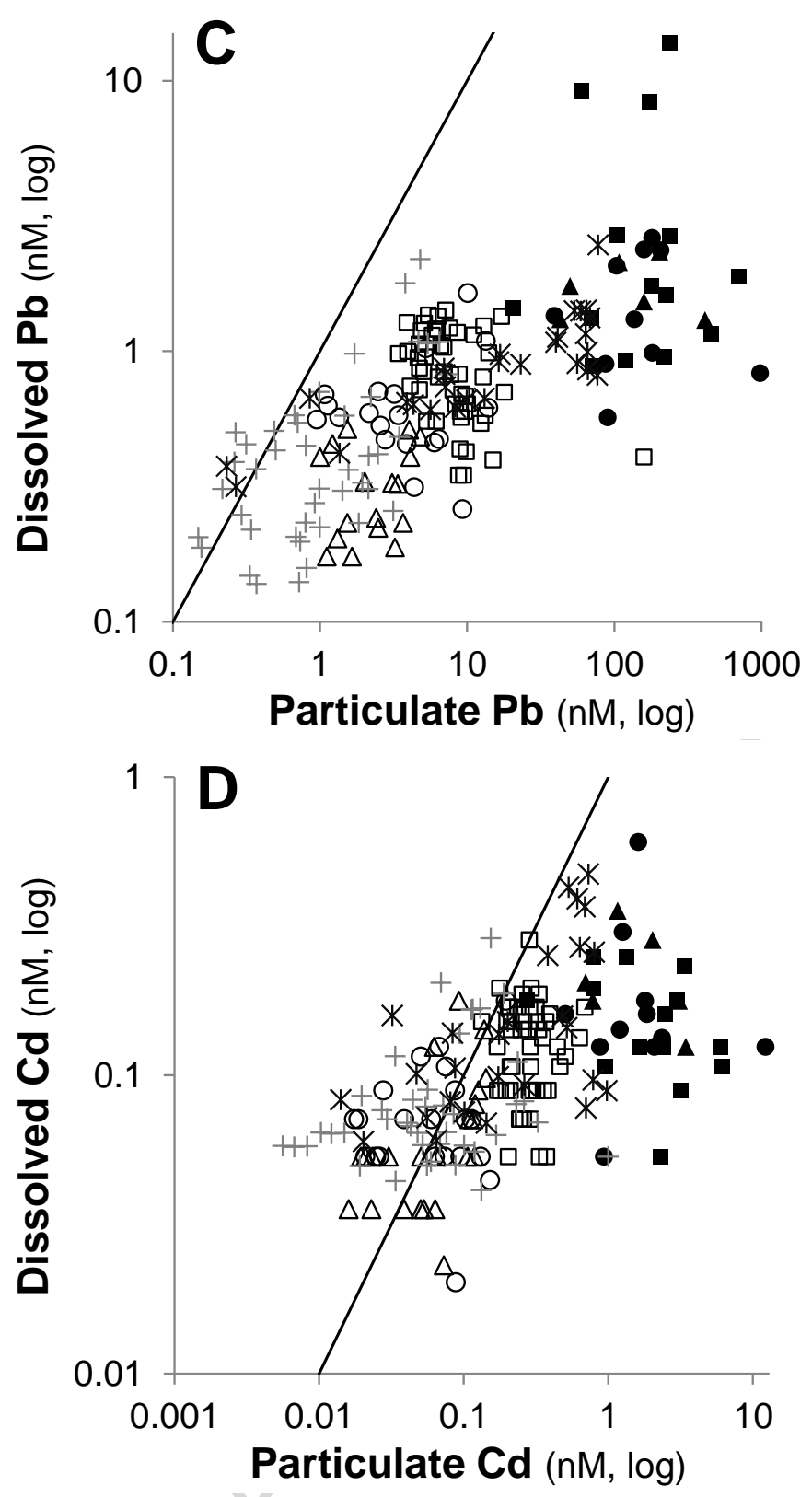

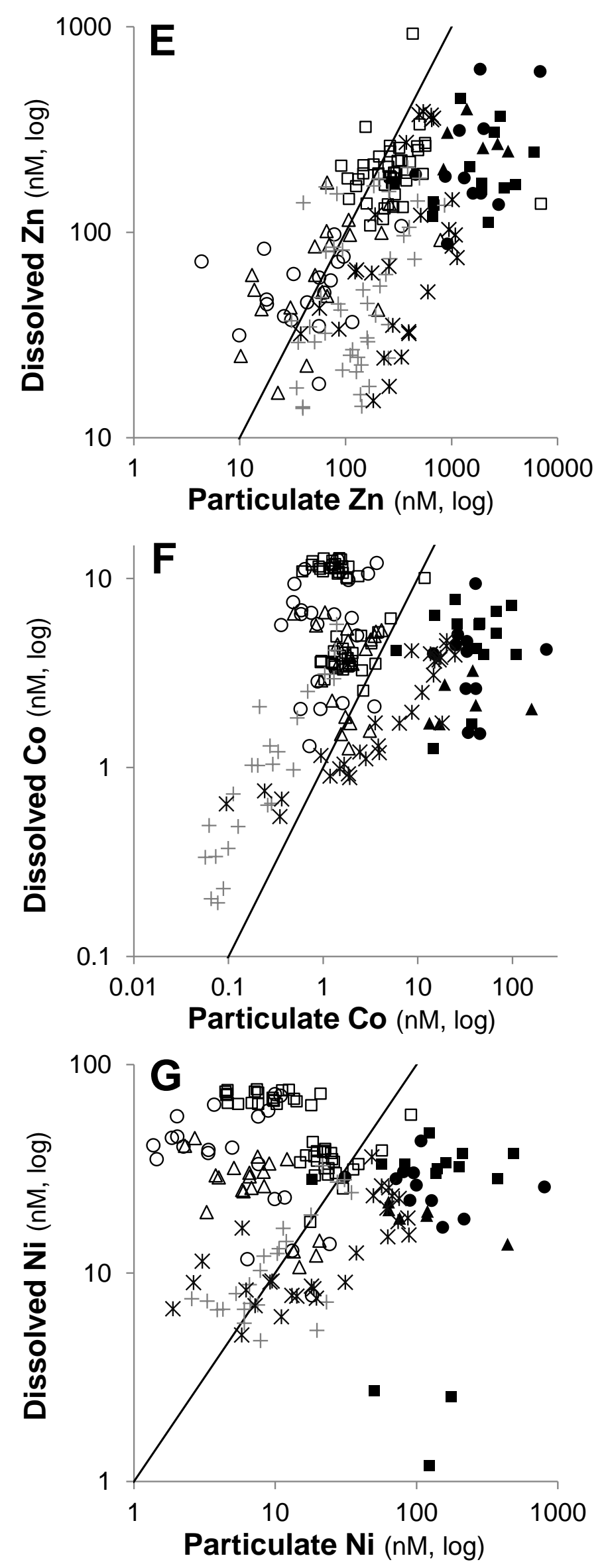
Oursel et al. Fig. 4
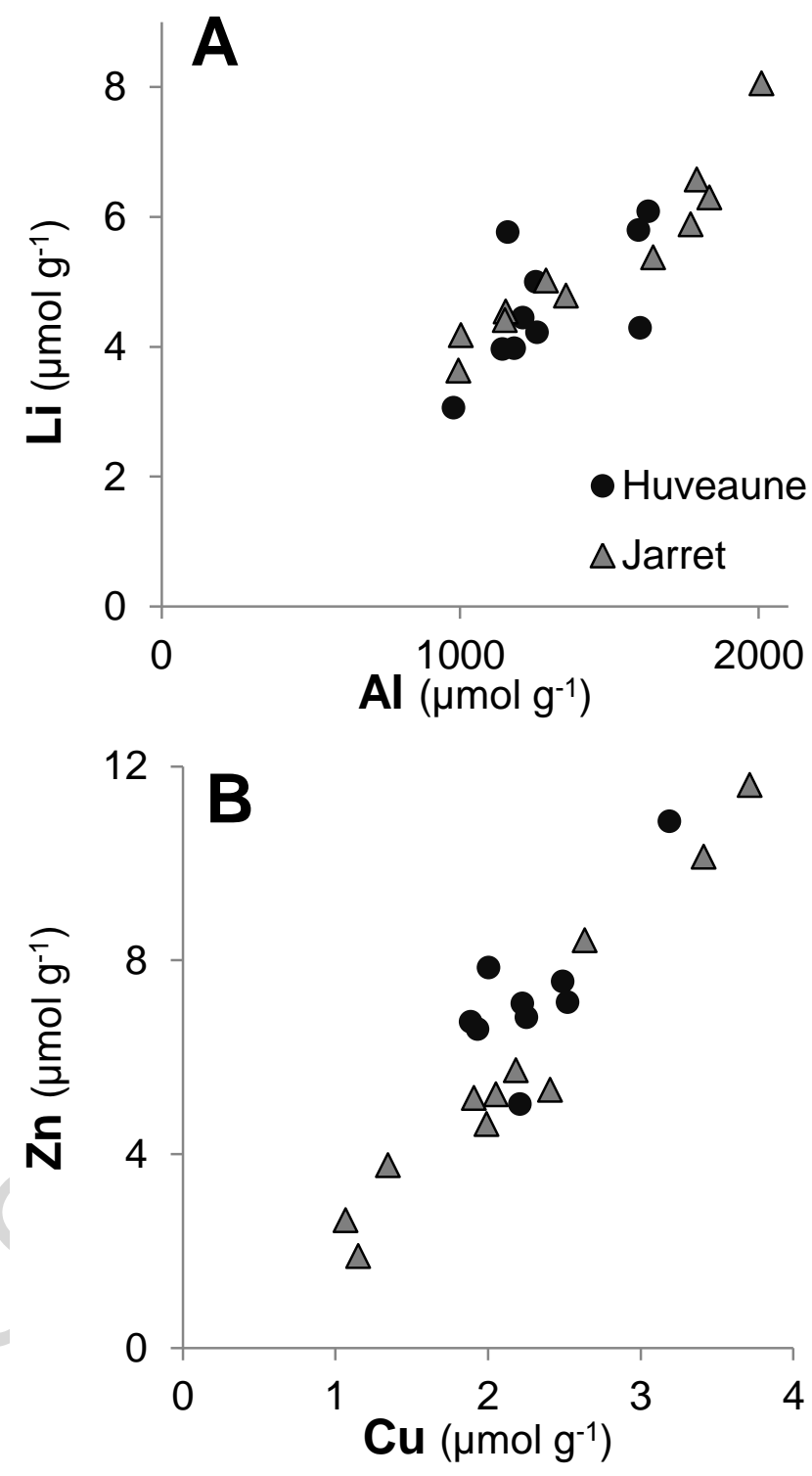
Oursel et al. Fig. 5
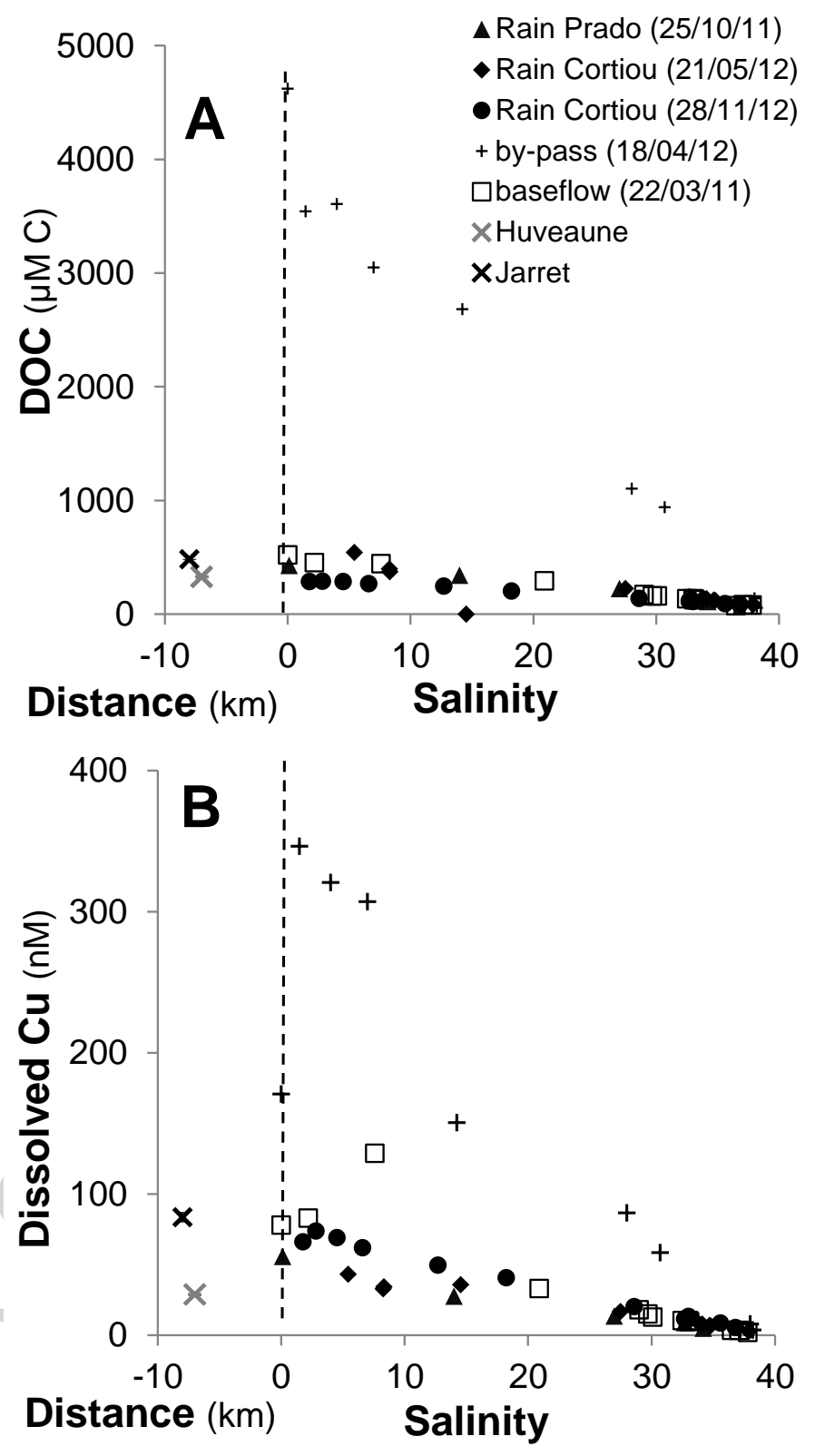

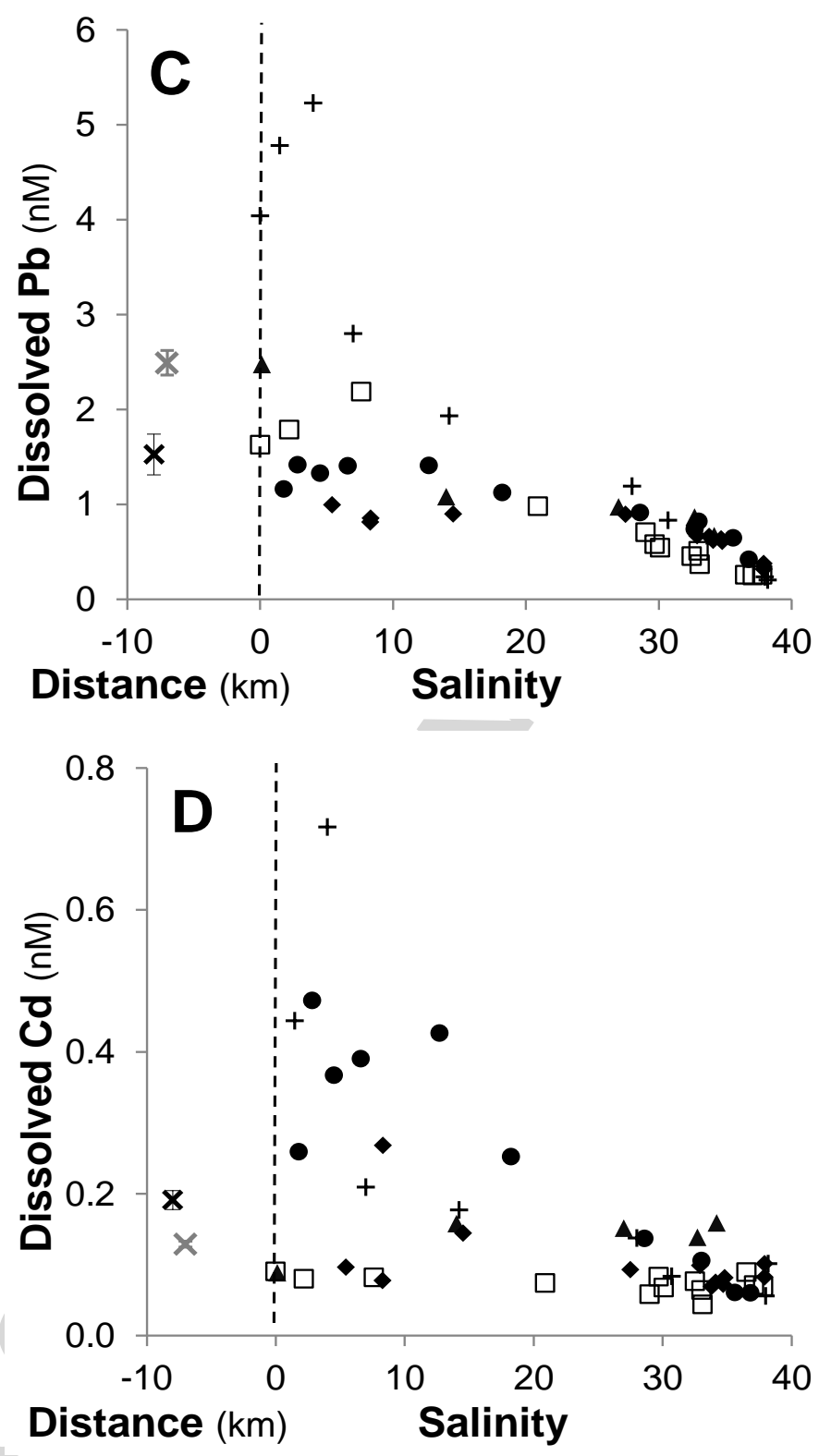

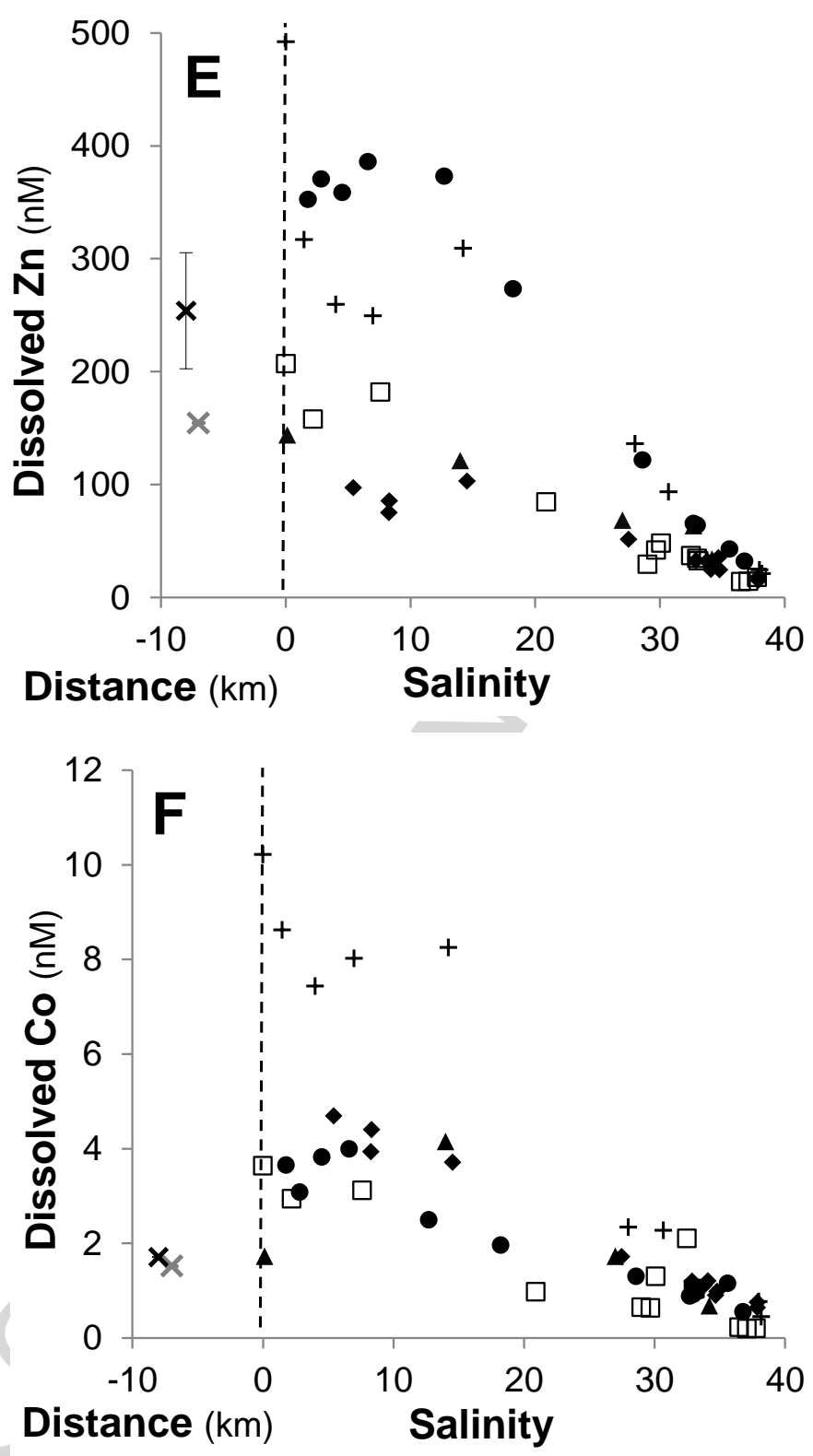

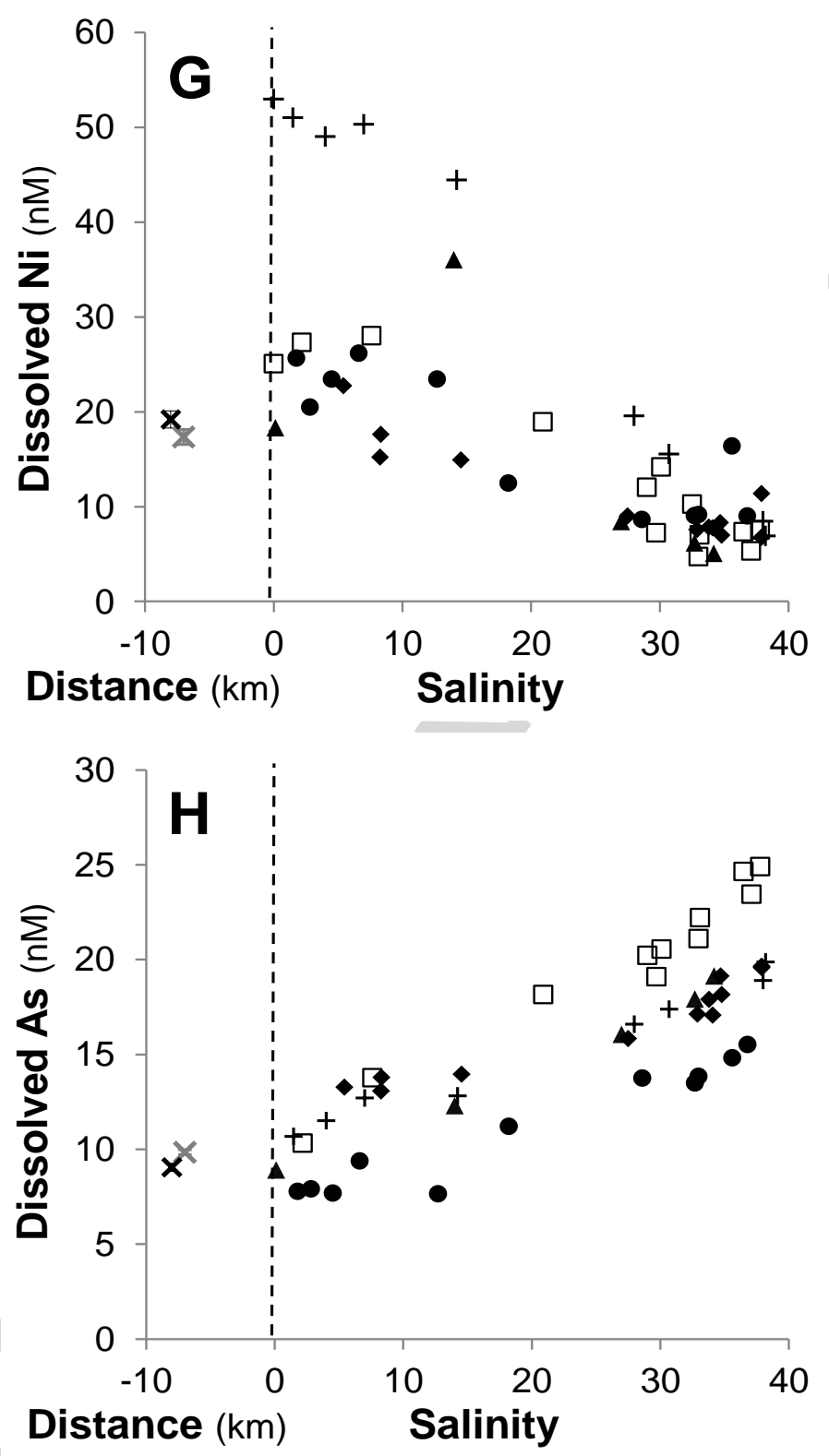
Oursel et al. Fig. 6
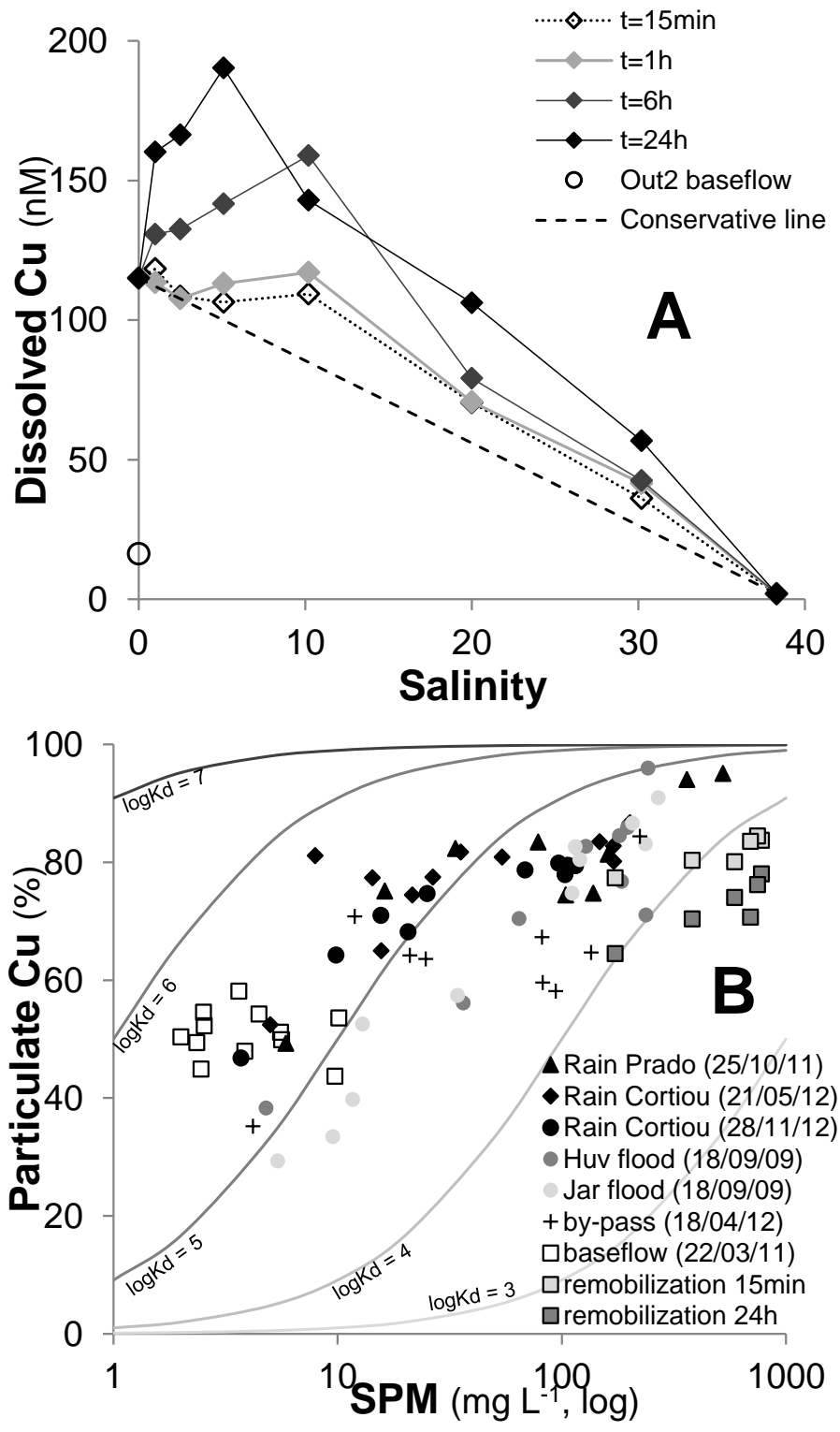

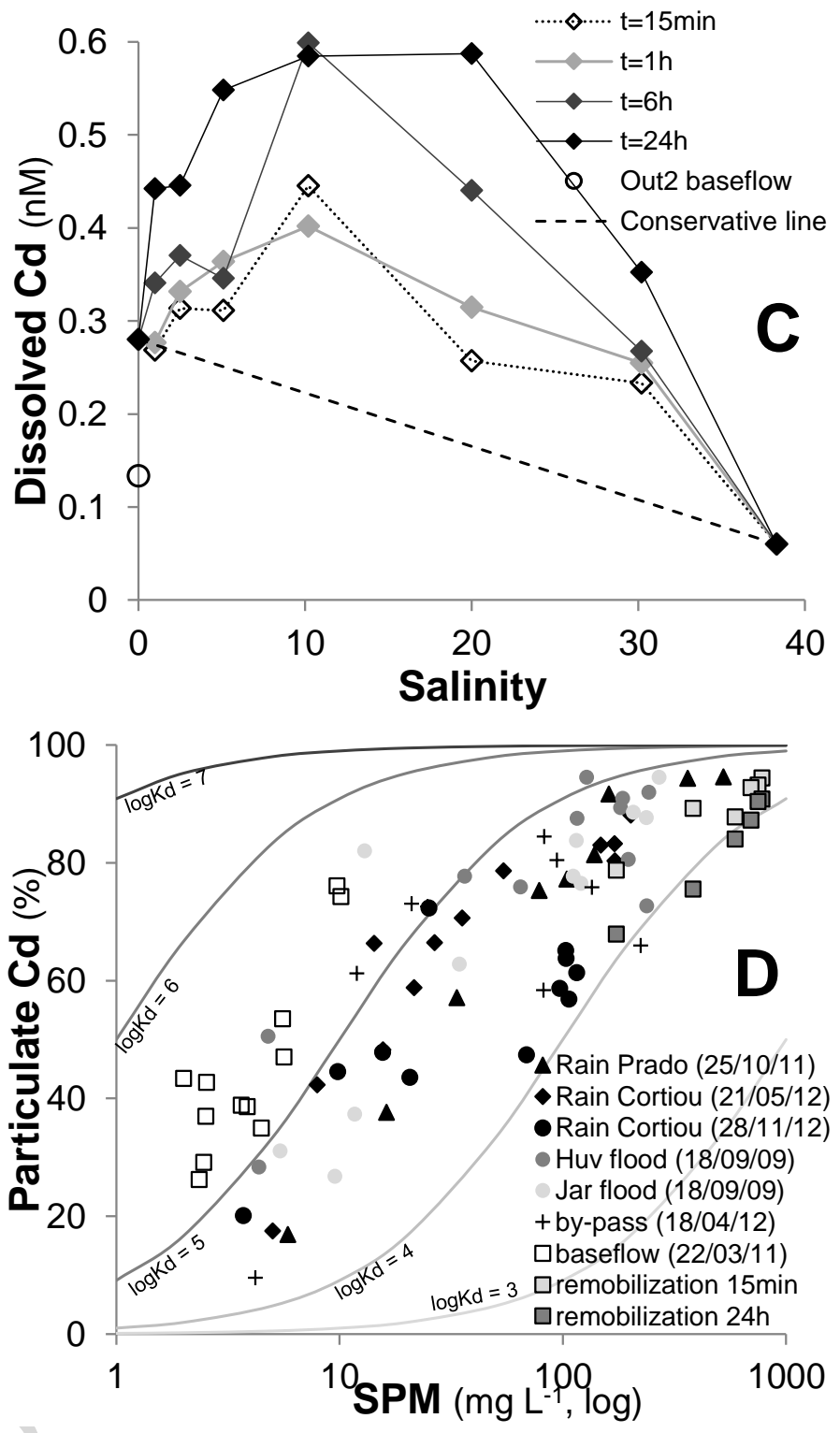

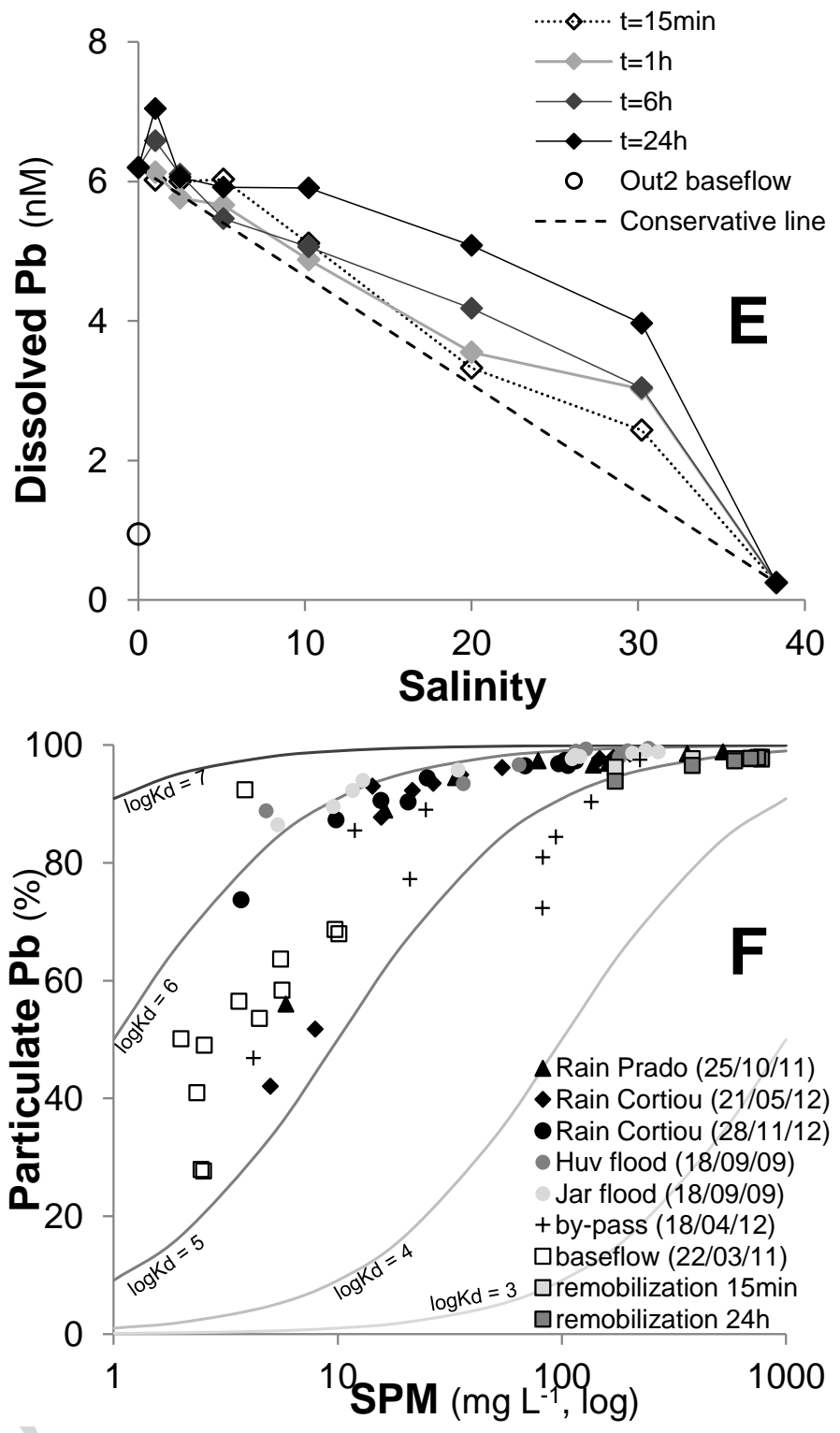


\section{Oursel et al. Table 1}

\begin{tabular}{|c|c|c|c|c|c|c|c|c|c|c|c|c|c|c|c|c|c|}
\hline & \multirow[t]{2}{*}{ SPM $\left(\mathrm{mg} \mathrm{L}^{-1}\right)$} & \multirow[t]{2}{*}{$\operatorname{DOC}(\mu \mathrm{M} C)$} & \multirow{2}{*}{$\operatorname{POC}\left(\mu \mathrm{mol} \mathrm{C} \mathrm{g}^{-1}\right)$} & \multicolumn{2}{|c|}{$\mathrm{Cu}(\mathrm{nM})$} & \multicolumn{2}{|c|}{$\mathrm{Pb}(\mathrm{nM})$} & \multicolumn{2}{|c|}{$\mathrm{Cd}(\mathrm{nM})$} & \multicolumn{2}{|c|}{$\mathrm{Zn}(\mathrm{nM})$} & \multicolumn{2}{|c|}{ Co $(n M)$} & \multicolumn{2}{|c|}{$\mathbf{N i}(n M)$} & \multicolumn{2}{|c|}{ As $(n M)$} \\
\hline & & & & D & $\mathrm{P}$ & D & $\mathrm{P}$ & D & $\mathrm{P}$ & D & $\mathrm{P}$ & D & $\mathrm{P}$ & D & $\mathrm{P}$ & D & $\mathrm{P}$ \\
\hline Huveaune-average & 200 & 400 & 5800 & 79 & 640 & 1.5 & 210 & 0.19 & 2.3 & 270 & 1900 & 4.0 & 48 & 27 & 160 & 9.9 & 38 \\
\hline$(\min -\max )$ & $(78-490)$ & $(190-480)$ & $(4300-7700)$ & (28-193) & $(140-2200)$ & $(0.57-2.6)$ & $(39-980)$ & $(0.05-0.60)$ & $(0.51-12)$ & $(88-620)$ & $(460-6900)$ & $(1.5-9.4)$ & $(15-230)$ & $(17-43)$ & $(31-800)$ & $(9.6-10)$ & $(24-50)$ \\
\hline Jarret-average & 230 & 530 & 7600 & 88 & 580 & 1.7 & 150 & 0.22 & 1.7 & 280 & 1700 & 2.3 & 44 & 19 & 140 & 9.1 & 17 \\
\hline$(\min -\max )$ & $(120-460)$ & $(310-720)$ & $(4600-10800)$ & $(33-130)$ & $(240-1400)$ & $(1.3-2.3)$ & $(43-420)$ & $(0.12-0.36)$ & $(0.7-3.4)$ & $(200-400)$ & $(630-3400)$ & $(1.7-3.3)$ & $(13-160)$ & $(14-22)$ & $(63-440)$ & $(9.0-9.1)$ & $(13-20)$ \\
\hline Outlet-average & 210 & 450 & 8300 & 59 & 680 & 3.5 & 210 & 0.16 & 2.5 & 210 & 2100 & 5.0 & 46 & 27 & 170 & N.M. & N.M. \\
\hline$(\min -\max )$ & $(35-590)$ & $(270-670)$ & $(4500-14200)$ & $(22-85)$ & $(100-1900)$ & $(0.88-14)$ & $(21-700)$ & $(0.05-0.25)$ & $(0.27-6.1)$ & $(110-450)$ & $(290-6000)$ & $(1.3-7.7)$ & $(5.9-110)$ & $(1.2-47)$ & $(18-490)$ & & \\
\hline Seawater-average & 4.5 & 83 & 3600 & 3.3 & 5.2 & 0.25 & 0.26 & 0.07 & 0.04 & 21 & 120 & 0.52 & 0.24 & 8.4 & 14 & 21 & 0.44 \\
\hline$(\min -\max )$ & $(3.1-6.0)$ & $(70-100)$ & $(1800-5400)$ & $(1.6-4.1)$ & $(1.9-9.2)$ & $(0.14-0.36)$ & $(0.04-0.37)$ & $(0.05-0.08)$ & (0.01-0.09) & $(14-31)$ & $(61-160)$ & $(0.22-1.0)$ & $(0.06-0.55)$ & (5.7-9.9) & $(6.1-20)$ & $(20-21)$ & $(0.32-0.54)$ \\
\hline Eygoutier-average & 260 & 1400 & 12500 & 52 & 720 & 5.6 & 230 & 0.051 & 14 & 20 & 3300 & N.M. & N.M. & N.M. & 120 & N.M. & N.M. \\
\hline Rhône-average & 660 & N.M. & N.M. & 31 & 260 & 0.34 & 98 & N.M. & 2.0 & 35 & 970 & N.M. & 87 & 18 & 310 & 27 & N.M. \\
\hline
\end{tabular}

N.M.: not measured 


\section{Figure caption}

Table 1: Variations of dissolved (D) and particulate (P) elements concentrations during flood conditions in the rivers, at the outlet and in the seawater end-member compared to the Eygoutier River (Nicolau et al., 2012) and to the Rhône River (Ollivier et al., 2011).

Figure 1: Map of the studied site: the dotted area represents the urbanized zone of Marseille, (inset) position of the sampling sites. Sampling points: O: outlet; Jar: Jarret River; Huv: Huveaune River.

Figure 2: Temporal variation of (A) the flow in both rivers and hour rainfall in Marseille; (B) the suspended particulate matter (SPM) and the turbidity; (C) the DOC and POC; (D) dissolved and particulate $\mathrm{Cu}$ during the 18/09/2009 flood events. In each figure, data points represent measurements on composite samples collected during one or two hours (see part 2.2.1.).

Figure 3: Variation of dissolved elements as a function of particulate elements expressed in $\mu \mathrm{M} \mathrm{C}$ for DOC/POC (A) and in $\mathrm{nM}$ for $\mathrm{Cu}(\mathrm{B}), \mathrm{Pb}(\mathrm{C}), \mathrm{Cd}(\mathrm{D}), \mathrm{Zn}(\mathrm{E}), \mathrm{Co}(\mathrm{F})$ and $\mathrm{Ni}$ (G) for all flood and baseflow period (Oursel et al., 2013) samples; the line (eq:eq) represents the same element concentration in the dissolved and particulate fractions.

Figure 4: Particulate contents variation of (A) $\mathrm{Li}$ vs. $\mathrm{Al}$ and (B) $\mathrm{Zn}$ vs. Cu during Huveaune and Jarret flood events.

Figure 5: Variation of DOC and dissolved metal in Huveaune and Jarret rivers, as a function of the distance until outlet, and from outlet to seawater, as a function of the salinity gradient for flood, baseflow (Oursel et al., 2013) and by-pass sampling campaigns for DOC (A), Cu (B), Pb (C), Cd (D), Zn (E), Co (F), Ni (G) and As (H); Error bar for the river points correspond to measured minimum-maximum range.

Figure 6: Dissolved $\mathrm{Cu}(\mathrm{A}), \mathrm{Cd}(\mathrm{C})$ and $\mathrm{Pb}(\mathrm{E})$ concentrations as a function of salinity after different contact time during the remobilization experiment; Particulate $\mathrm{Cu}(\mathrm{B}), \mathrm{Cd}(\mathrm{D})$ and $\mathrm{Pb}(\mathrm{F})$ fraction vs. suspended particulate matter (SPM) concentration for the various studied conditions compared to theoretical lines for given $\log K d$ values. 